\title{
Analysis of Control Rod Drop Accidents for the Canadian SCWR Using Coupled 3-Dimensional Neutron Kinetics and Thermal Hydraulics
}

\author{
Frederic Salaun (iD) and David R. Novog (iD \\ McMaster University, 1280 Main Street West, Hamilton, ON, Canada L8S 4L8 \\ Correspondence should be addressed to Frederic Salaun; salaunf@mcmaster.ca
}

Received 1 November 2017; Accepted 11 December 2017; Published 22 January 2018

Academic Editor: Eugenijus Ušpuras

Copyright (C) 2018 Frederic Salaun and David R. Novog. This is an open access article distributed under the Creative Commons Attribution License, which permits unrestricted use, distribution, and reproduction in any medium, provided the original work is properly cited.

\begin{abstract}
The Canadian Supercritical Water-cooled Reactor (SCWR), a GEN IV reactor design, is a hybrid design of the well-established $\mathrm{CANDU}^{\mathrm{TM}}$ and Boiling Water Reactor with water above its thermodynamic critical point. Given the batch fueled design, control rods are used to manage the reactivity throughout the fuel cycle. This paper examines the consequences of a control rod drop accident (CRDA) for the Canadian SCWR. The asymmetry generated by the dropped rod requires an accurate 3-dimensional neutron kinetics calculation coupled to a detailed thermal-hydraulic model. Before simulating the CRDAs, the proper implementation of the $3 \mathrm{D}$ reactivity feedback was verified and various sensitivity studies were performed. This work demonstrates that the proposed safety systems for the SCWR core are capable of terminating the CRDA sequence prior to exceeding maximum sheath and centerline temperatures. In one instance involving a rod on the periphery of the core, the proposed trip setpoint (115\% FP) was not exceeded and a new steady state was reached. Therefore it is recommended that the design also include provisions for a high-log rate and/or local Neutron Overpower Protection (NOP) trips, similar to existing CANDU designs such that reactor shutdown can be assured for such spatial anomalies.
\end{abstract}

\section{Introduction}

The Canadian Supercritical Water-cooled Reactor (SCWR) design is the result of the fusion of a CANDU reactor and a Boiling Water Reactor (BWR) [1]. The vertical orientation of the core and large light water density variation along the channel resembles the latter while the pressure-tube technology and separate low-pressure (0.3 $\mathrm{MPa}$ ) heavy-water moderator are inspired from the CANDU design (Figure 1). It is important to note that the light water coolant $\left(25 \mathrm{MPa}, 350^{\circ} \mathrm{C}\right.$ inlet) is in the supercritical condition and therefore there is no phase change as the coolant heats up along the channel $\left(625^{\circ} \mathrm{C}\right.$ outlet). The batch refueling design necessitates a large excess reactivity at beginning of cycle; therefore two reactivity control systems were designed for the Canadian SCWR. A burnable absorber $\left(\mathrm{Gd}_{2} \mathrm{O}_{3}\right)$ was integrated into a selected number of fuel pins and 89 adjustable cruciform control rods can be inserted from the bottom of the core into the low-pressure moderator [2]. The core is composed of 336 fuel assemblies which generate a thermal power of $2032 \mathrm{MW}$ leading to approximately $1000 \mathrm{MW}_{\mathrm{el}}(\sim 48 \%$ efficiency).

Nuclear reactors can be subjected to a wide variety of conditions ranging from normal operations to postulated accidents. As a consequence, safety analyses are performed to evaluate the impact of such transients and the performance of the special safety systems and to ensure that safety limits are not exceeded. Evaluation of the conceptual designs of several GEN IV SCWRs has been performed as outlined below.

The High Performance Light Water Reactor (HPLWR), a European design, has already been subjected to extensive analyses of turbine trips, loss of coolant accidents (LOCAs), and loss of flow accidents (LOFAs) [3]. The transient created by a turbine trip/load rejection was expected to be relatively severe; however the detailed analysis showed large margins. Analysis of LOCA scenarios demonstrated cladding temperatures up to $849^{\circ} \mathrm{C}$ which is well below the $1204^{\circ} \mathrm{C}$ safety limit. Finally, LOFAs without reactor SCRAM did not show any issues as the thermal limits were not exceeded; however, 


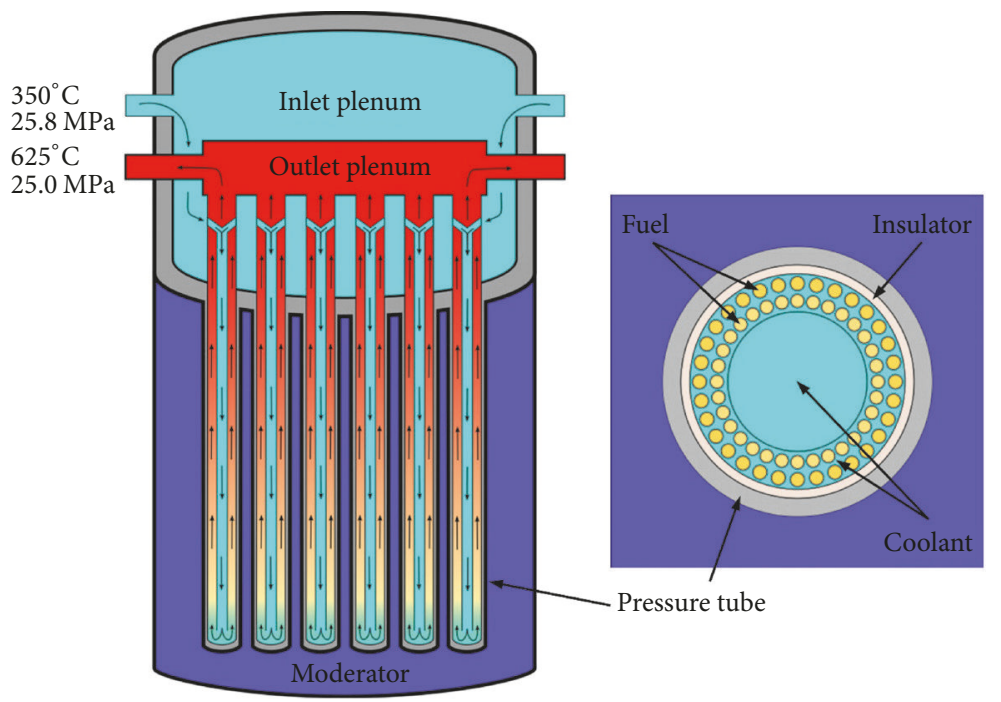

FIgURE 1: Canadian SCWR concept.

the author recommended a 3D kinetics model in future studies to confirm the validity of the point-kinetics model. All these thermal-hydraulic driven accidents showed acceptable consequences but more challenging results were observed during reactivity initiated accidents (RIAs). Uncontrolled withdrawal of control rods and control rod ejections without SCRAM were investigated in $[3,4]$. The maximum allowed cladding and fuel temperature were not exceeded; however the margins in some cases were very small. Additional studies of uncontrolled withdrawal of control rods without SCRAM, loss of feedwater heating, and control rod malfunction [5] showed that the last two transients have large margins to the safety limits; however the control rod withdrawal leads to fuel melting and emphasizes the importance of RIAs analyses. Finally, potential xenon oscillations also have to be investigated despite being a much slower transient [6]. Xenon stability analysis was then performed for the HPLWR and concluded that xenon oscillations are nonexistent [7].

The Super Light Water Reactor (Super LWR), a Japanese SCWR concept, evaluated the impact of a small and large LOCA, a LOFA, a loss of turbine flow, a pressure control system failure, and an uncontrolled CR withdrawal at normal operation [8]. While the maximum cladding surface temperature (MCST) always remained within the acceptable range, the maximum fuel centerline temperature (MFCLT) was not evaluated [9]. Given the importance of MFCLT in RIA transients it is difficult to assess the performance under these conditions. A mixed spectrum SCWR (SCWR-M) proposed by Cheng et al. [10] investigated LOFAs and met the safety criteria as long as few design features were respected [11]. In addition, LOCAs were carried out for many break sizes and in the most detrimental case, the MCST largely exceeded the safety criterion which will lead to further core optimization [12].

Thus far only thermal-hydraulic driven accident scenarios (LOCA, LOFA) have been investigated for the Canadian SCWR. While the coolant void reactivity (CVR) for the design was negative, studies demonstrate a positive reactivity insertion under nonequilibrium voiding conditions $[13,14]$. As can be seen in Figure 1, the coolant enters at the top of the core from the inlet plenum through channel specific orifices and travels downwards in the central tube. When the coolant reaches the bottom of the channel it turns arounds and travels upwards picking up the heat from the $64(\mathrm{Pu}, \mathrm{Th}) \mathrm{O}_{2}$ fuel pins. The positive reactivity insertion happens when the coolant first voids around the fuel pins and was studied using coupled 3D neutron kinetics and thermal-hydraulic simulations for thermal-hydraulic driven transients [15]. The inlet LOCA resulted in a flow reversal leading first to a coolant density decrease around the fuel which generated a power pulse before being terminated by the fuel Doppler effect as well as the large central tube coolant density feedback. An inlet LOCA with loss of emergency core cooling systems was also investigated in [16] and evaluated a MCST up to $1278^{\circ} \mathrm{C}$ which is just above the $1260^{\circ} \mathrm{C}$ safety limit.

The work carried out in this study presents the first reactivity initiated accidents for the Canadian SCWR. Given the importance of RIA in the literature review of the HPLWR, it is important that such accidents be analyzed for the Canadian design. Such accidents may involve highly localized phenomena and reactivity feedback, thus necessitating a 3dimensional neutron kinetics analysis coupled to thermal hydraulics simulations. A very fast control rod ejection is not considered for the Canadian SCWR as the control rods are inserted in the low-pressure moderator which is different from Light Water Reactor (LWR) technologies where the rods are surrounded by high pressure coolant. However, a control rod can fall under the action of gravity and lead to a control rod drop accident (CRDA). The initiating event, which is the separation of a control rod from its driving mechanism, is considered identical to a BWR's as the control rod design is similar [17]. The incident can occur at any time of the fuel cycle and for any control rod, leading to a local reduction in neutron absorption which in turn increases the fission rate causing a fast and localized power excursion in the 


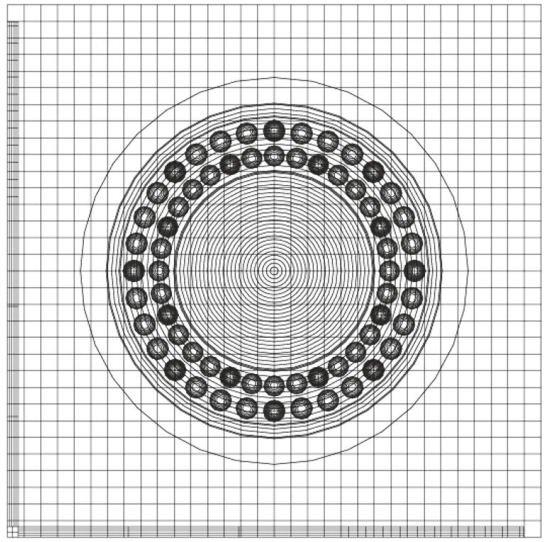

(a)

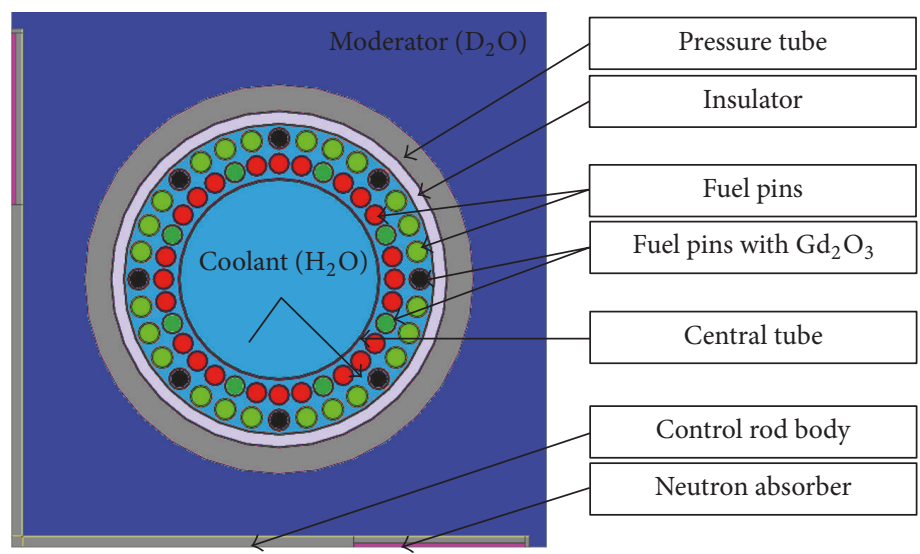

(b)

Figure 2: Fuel lattice cell meshing (a) and materials (b).

reactor core. Such local phenomena cannot be assessed using point-kinetics approximations. Moreover, neutron physics and thermal-hydraulic parameters are intrinsically coupled and play an important role during the transient by providing reactivity feedback mechanisms [18-20]. As a consequence, a 3D neutron kinetics model was built in PARCS [21] and has been coupled to RELAP/SCDAPSIM/MOD4 [22] through a series of external python scripts to provide a comprehensive prediction of the transient core response during RIA events.

\section{Canadian SCWR Core Modelling}

This section presents the reactor physics and thermal hydraulics models built to simulate the Canadian SCWR.

\subsection{Lattice Physics Modelling}

2.1.1. Fuel Cell Lattice. The fuel channel geometry and materials specifications for the Canadian SCWR lattice are summarized in Table 1. A total of $64(\mathrm{Pu}, \mathrm{Th}) \mathrm{O}_{2}$ fuel pins are surrounded by a supercritical light water coolant contained in a pressure tube sitting in the heavy-water moderator. TRITON [23] was used to simulate the fuel lattice cell with depletion using the model shown in Figure 2. Reflective boundary conditions were applied on the sides of the cell and the 238-energy group neutron transport equation was solved to obtain the flux distribution within the cell. Using a flux weighting process, the cross sections were homogenized and condensed in 2 energy groups with an energy cutoff of $2.57 \mathrm{eV}[24,25]$. The fuel materials were then depleted with ORIGEN [23] and this entire process was repeated until a burnup of approximately $70 \mathrm{MW} \cdot \mathrm{d} / \mathrm{kg}$. Given the fuel enrichment and burnable absorber grading in the axial direction as well as changing thermal-hydraulic conditions along the channel, fuel lattice calculations were performed at 20 axial elevations (see Tables 2 and 3). The thermalhydraulic conditions (coolant temperature and properties, material temperatures, and properties) were taken from [26]. Finally, the kinetics parameters (neutron velocity, delayed neutron fractions, and lambdas) were evaluated at each depletion step for the 20 elevations as recommended in [27], hence providing the model with locally varying kinetics parameters. These runs represent the reference state of the lattice calculations. Additional sensitivity calculations were performed to assess the impact of lattice cell meshing to ensure accurate lattice cell cross sections are determined.

Branch calculations have also been performed to evaluate the sensitivity of the reference lattice homogenized cross sections to important thermal-hydraulic and control system perturbations. The branches listed in Table 3 were simulated at every axial elevation and several burnup steps by perturbing the reference thermal-hydraulic parameter (see Table 2) as well as simulating the insertion or removal of the control rod. It has to be noted that even though the coolant in the central tube and between the fuel pins is the same, their impact on the lattice physics phenomena is very different [14]. Since nonequilibrium voiding transients may occur each coolant region is treated separately by having separate branches for the inner and outer coolant regions. These branch calculations were used by PARCS to interpolate new cross sections depending on the local thermal-hydraulic conditions calculated by RELAP/SCDAPSIM/MOD4 and based on control rod positions. In [26], the cross sections interpolation technique was demonstrated to perform well for the studied transient.

Finally, the reflector cross sections were generated through a multicell geometry as shown in Figure 3. Sensitivity studies demonstrated that the fuel type and thermalhydraulic conditions of the four fuel assemblies did not significantly change the reflector properties. Therefore, the reflector's cross sections were evaluated using the fuel assembly's thermal-hydraulic conditions at the bottom of the core and for fresh fuel. Moreover, it was found that homogenizing the entire reflector region in the multicell to generate the reflector's cross sections and applying it to every reflector cell in the diffusion model were also a good approximation.

2.1.2. Full-Core Diffusion Model. The 336 fuel channels are surrounded by a $100 \mathrm{~cm}$ thick radial reflector and $75 \mathrm{~cm}$ axial reflector at the top and bottom of the core. The fuel channel is divided into 20 axial positions using the corresponding 
TABLE 1: Fuel lattice cell specifications.

\begin{tabular}{|c|c|c|c|c|}
\hline Component & Dimension & Material & Composition [wt\%] & Density $\left[\mathrm{g} \cdot \mathrm{cm}^{-3}\right]$ \\
\hline $\begin{array}{l}\text { Centre tube } \\
\text { coolant }\end{array}$ & $4.6 \mathrm{~cm}$ radius & Light water & $100 \% \mathrm{H} 2 \mathrm{O}$ & Variable \\
\hline Centre flow tube & $\begin{array}{l}4.60 \mathrm{~cm} \text { inner radius; } \\
0.1 \mathrm{~cm} \text { thick }\end{array}$ & Zr-modified 310 stainless steel & $\begin{array}{c}\text { C: 0.034; Si: 0.51; Mn: 0.74; P: 0.016; S: } \\
\text { 0.002; Ni: 20.82; Cr: 25.04; Fe: 51.738; Mo: } \\
\text { 0.51; Zr: } 0.59\end{array}$ & 7.9 \\
\hline \multirow{3}{*}{ Inner fuel pins (24) } & \multirow{3}{*}{$\begin{array}{l}0.415 \mathrm{~cm} \text { radius; } \\
5.4 \mathrm{~cm} \text { pitch radius }\end{array}$} & $0-3 \mathrm{~m} \mid 12.8$ wt $\% \mathrm{PuO}_{2}$ in $\mathrm{ThO}_{2}$ & Pu: 11.293; Th: 76.632; O: 12.075 & \multirow{3}{*}{9.91} \\
\hline & & $3-4 \mathrm{~m} \mid 12.3 \mathrm{wt} \% \mathrm{PuO}_{2}$ in $\mathrm{ThO}_{2}$ & Pu: 10.851; Th: 77.072; O: 12.077 & \\
\hline & & $4-5 \mathrm{~m} \mid 11.5 \mathrm{wt} \% \mathrm{PuO}_{2}$ in $\mathrm{ThO}_{2}$ & Pu: 10.146; Th: 77.775; O: 12.079 & \\
\hline \multirow{3}{*}{$\begin{array}{l}\text { Outer fuel pins } \\
(24)\end{array}$} & \multirow{3}{*}{$\begin{array}{c}0.44 \mathrm{~cm} \text { radius; } \\
6.575 \mathrm{~cm} \text { pitch radius }\end{array}$} & $0-3 \mathrm{~m} \mid 10.24 \mathrm{wt} \% \mathrm{PuO}_{2}$ in $\mathrm{ThO}_{2}$ & Pu: 9.034; Th: 78.882; O: 12.084 & \multirow{3}{*}{9.87} \\
\hline & & 3-4 m | 9.84 wt $\% \mathrm{PuO}_{2}$ in $\mathrm{ThO}_{2}$ & Pu: 8.682; Th: 79.233; O: 12.085 & \\
\hline & & $4-5 \mathrm{~m} \mid 9.20$ wt $\% \mathrm{PuO}_{2}$ in $\mathrm{ThO}_{2}$ & Pu: 8.117; Th: 79.796; O: 12.087 & \\
\hline \multirow{3}{*}{$\begin{array}{l}\text { Inner fuel pins } \\
\text { with burnable } \\
\text { absorber (8) }\end{array}$} & \multirow{3}{*}{$\begin{array}{l}0.415 \mathrm{~cm} \text { radius; } \\
5.4 \mathrm{~cm} \text { pitch radius } \\
\text { (evenly spaced, } \pi / 8 \\
\text { angular offset) }\end{array}$} & $\begin{array}{c}0-3 \mathrm{~m} \mid 12.8 \mathrm{wt} \% \mathrm{PuO}_{2} \text { in } \mathrm{ThO}_{2} \\
3 \mathrm{wt} \% \mathrm{Gd}_{2} \mathrm{O}_{3} \text { in } \mathrm{PuO}_{2} / \mathrm{ThO}_{2}\end{array}$ & Pu: 10.954; Th: 74.333; O: 12.11; Gd: 2.603 & 9.82 \\
\hline & & $\begin{array}{c}3-4 \mathrm{~m} \mid 12.3 \mathrm{wt} \% \mathrm{PuO}_{2} \text { in } \mathrm{ThO}_{2} \\
2 \mathrm{wt} \% \mathrm{Gd}_{2} \mathrm{O}_{3} \text { in } \mathrm{PuO}_{2} / \mathrm{ThO}_{2}\end{array}$ & Pu: 10.635; Th: 75.53; O: 12.10; Gd: 1.735 & 9.85 \\
\hline & & $\begin{array}{c}4-5 \mathrm{~m} \mid 11.5 \text { wt } \% \mathrm{PuO}_{2} \text { in } \mathrm{ThO}_{2} \\
2 \mathrm{wt} \% \mathrm{Gd}_{2} \mathrm{O}_{3} \text { in } \mathrm{PuO}_{2} / \mathrm{ThO}_{2}\end{array}$ & Pu: 9.943; Th: 76.219; O: 12.103; Gd: 1.735 & 9.85 \\
\hline \multirow{3}{*}{$\begin{array}{l}\text { Outer fuel pins } \\
\text { with burnable } \\
\text { absorber }(8)\end{array}$} & \multirow{3}{*}{$\begin{array}{l}0.44 \mathrm{~cm} \text { radius; } \\
6.575 \mathrm{~cm} \text { pitch radius } \\
\text { (evenly spaced, no } \\
\text { angular offset) }\end{array}$} & $\begin{array}{c}0-3 \mathrm{~m} \mid 10.24 \text { wt } \% \mathrm{PuO}_{2} \text { in } \mathrm{ThO}_{2} \\
3 \text { wt } \% \mathrm{Gd}_{2} \mathrm{O}_{3} \text { in } \mathrm{PuO}_{2} / \mathrm{ThO}_{2}\end{array}$ & Pu: 8.764; Th: 76.515; O: 12.118; Gd: 2.603 & 9.79 \\
\hline & & $\begin{array}{l}\text { 3-4 } \mathrm{m} \mid 9.84 \mathrm{wt} \% \mathrm{PuO}_{2} \text { in } \mathrm{ThO}_{2} \\
2 \mathrm{wt} \% \mathrm{Gd}_{2} \mathrm{O}_{3} \text { in } \mathrm{PuO}_{2} / \mathrm{ThO}_{2}\end{array}$ & Pu: 8.508; Th: 77.649; O: 12.108; Gd: 1.735 & 9.81 \\
\hline & & $\begin{array}{c}\text { 4-5 m | 9.20 wt } \% \mathrm{PuO}_{2} \text { in } \mathrm{ThO}_{2} \\
2 \mathrm{wt} \% \mathrm{Gd}_{2} \mathrm{O}_{3} \text { in } \mathrm{PuO}_{2} / \mathrm{ThO}_{2}\end{array}$ & Pu: 7.955; Th: 78.20; O: 12.11; Gd: 1.735 & 9.81 \\
\hline Cladding & $0.06 \mathrm{~cm}$ thick & Zr-modified 310 stainless steel & As above & 7.9 \\
\hline Coolant & & Light water & $100 \% \mathrm{H} 2 \mathrm{O}$ & Variable \\
\hline Liner tube & $\begin{array}{l}7.2 \mathrm{~cm} \text { inner radius; } \\
0.05 \mathrm{~cm} \text { thick }\end{array}$ & Zr-modified 310 stainless steel & As above & 7.9 \\
\hline Insulator & $\begin{array}{l}7.25 \mathrm{~cm} \text { inner radius; } \\
0.55 \mathrm{~cm} \text { thick }\end{array}$ & Yttria stabilized Zirconia & Zr: 66.63; Y: 7.87; O: 25.5 & 5.37 \\
\hline Outer liner tube & $\begin{array}{l}7.8 \mathrm{~cm} \text { inner radius; } \\
0.05 \mathrm{~cm} \text { thick }\end{array}$ & Excel aloy & Sn: $3.5 ; \mathrm{Mo:} 0.8 ; \mathrm{Nb}: 0.8 ; \mathrm{Zr} 94.9$ & 6.52 \\
\hline Pressure tube & $\begin{array}{l}7.85 \mathrm{~cm} \text { inner radius; } \\
1.2 \mathrm{~cm} \text { thick }\end{array}$ & Excel alloy & Sn: 3.5; Mo: 0.8; Nb: 0.8; Zr 94.9 & 6.52 \\
\hline Moderator & $\begin{array}{l}25 \mathrm{~cm} \text { square lattice } \\
\text { pitch }\end{array}$ & Heavy water & 99.833 D2O; 0.167 H2O & 1.0851 \\
\hline $\begin{array}{l}\text { Plutonium } \\
\text { isotopics }\end{array}$ & & Reactor grade plutonium & $\begin{array}{l}\text { Pu238: 2.75; Pu239: 51.96; Pu240: 22.96; } \\
\text { Pu241: 15.23; Pu242: 7.10 }\end{array}$ & \\
\hline Control blade body & $\begin{array}{l}\text { Span } 48.4 \mathrm{~cm} \text {; } \\
\text { thickness } 1 \mathrm{~cm} \text {; }\end{array}$ & Excel alloy & Sn: 3.5; Mo: 0.8; Nb: 0.8; Zr: 94.9 & 6.52 \\
\hline $\begin{array}{l}\text { Control blade } \\
\text { absorber }\end{array}$ & $\begin{array}{l}\text { Position on the blade's } \\
\text { arm: } 16-24 \mathrm{~cm} ; \\
\text { thickness } 0.8 \mathrm{~cm}\end{array}$ & Stainless steel 304 & & 7.94 \\
\hline
\end{tabular}

2-group cross sections evaluated at the lattice level (Figure 3). Zero incoming current boundary conditions were applied on the edge of the reflector. The control rods are inserted through the bottom of the core similar to a BWR and their location is depicted in Figure 4 (for 1/8th of the core due to the symmetry). A separate module, VERAview [28], was used for visualization of the transients result.

2.2. Thermal-Hydraulic Model. The original RELAP/ SCDAPSIM/MOD4 (RSM4) [22] source code was previously modified to correct for the water properties at supercritical conditions in [29]. Each of the 336 fuel channels is simulated in this work; however due to limitations in RSM4 not all channels are simulated simultaneously. Therefore the core was divided into eight identical zones and RSM4 simulations were performed for each of the eight regions successively (Figure 5). Each of the eight separate RSM4 models has a fixed inlet boundary condition $\left(25.8 \mathrm{MPa}, 350^{\circ} \mathrm{C}\right)$, an inlet plenum, 46 parallel channels with individual static orifices, an outlet plenum, and a $25 \mathrm{MPa}$ fixed outlet boundary condition (Figure 6). The power in each channel was split 


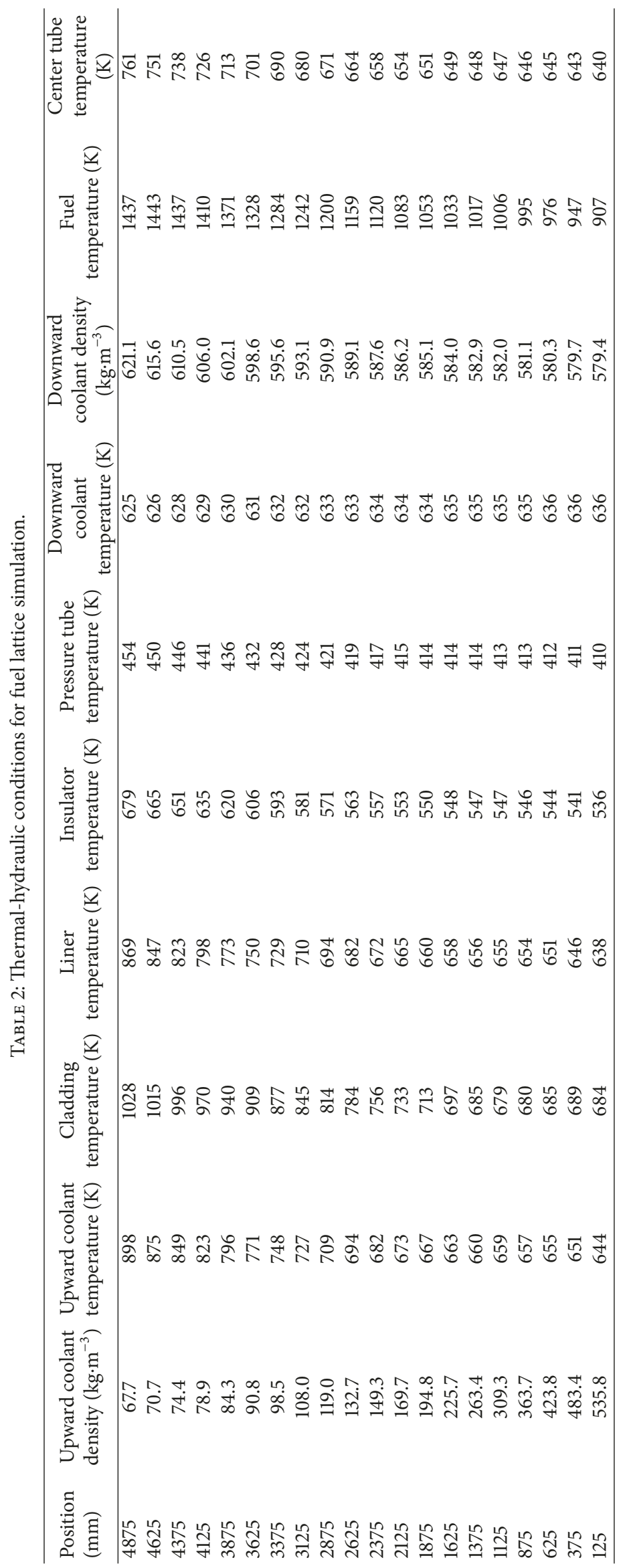


TABLE 3: Branches definitions for cross-sections interpolation.

\begin{tabular}{|c|c|c|c|c|c|c|}
\hline \multirow[b]{2}{*}{ Branches } & \multirow{2}{*}{$\begin{array}{c}\text { Control rod } \\
\begin{array}{c}0=\text { out } \\
1=\text { in }\end{array}\end{array}$} & \multicolumn{2}{|c|}{ Central tube } & \multirow{2}{*}{$\begin{array}{c}\text { Fuel } \\
\text { Temperature (K) }\end{array}$} & \multicolumn{2}{|c|}{ Coolant around fuel pins } \\
\hline & & Density $\left(\mathrm{g} \cdot \mathrm{cm}^{-3}\right)$ & Temperature (K) & & Density $\left(\mathrm{g} \cdot \mathrm{cm}^{-3}\right)$ & Temperature (K) \\
\hline 0 (reference) & 0 & $\rho_{\text {ref_cooll }}$ & $T_{\text {ref_cooll }}$ & $T_{\text {ref_fuel }}$ & $\rho_{\text {ref_cool2 }}$ & $T_{\text {ref_cool2 }}$ \\
\hline 1 & 1 & - & - & - & - & - \\
\hline 2 & 0 & 0.02 & - & - & - & - \\
\hline 3 & 0 & 0.70 & - & - & - & - \\
\hline 4 & 0 & - & 600 & - & - & - \\
\hline 5 & 0 & - & 1000 & - & - & - \\
\hline 6 & 0 & - & - & 600 & - & - \\
\hline 7 & 0 & - & - & 2000 & - & - \\
\hline 8 & 0 & - & - & - & 0.02 & - \\
\hline 9 & 0 & - & - & - & 0.70 & - \\
\hline 10 & 0 & - & - & - & - & 650 \\
\hline 11 & 0 & - & - & - & - & 1000 \\
\hline 12 & 1 & 0.02 & - & - & - & - \\
\hline 13 & 1 & 0.70 & - & - & - & - \\
\hline 14 & 1 & - & 600 & - & - & - \\
\hline 15 & 1 & - & 1000 & - & - & - \\
\hline 16 & 1 & - & - & 600 & - & - \\
\hline 17 & 1 & - & - & 2000 & - & - \\
\hline 18 & 1 & - & - & - & 0.02 & - \\
\hline 19 & 1 & - & - & - & 0.70 & - \\
\hline 20 & 1 & - & - & - & - & 650 \\
\hline 21 & 1 & - & - & - & - & 1000 \\
\hline
\end{tabular}

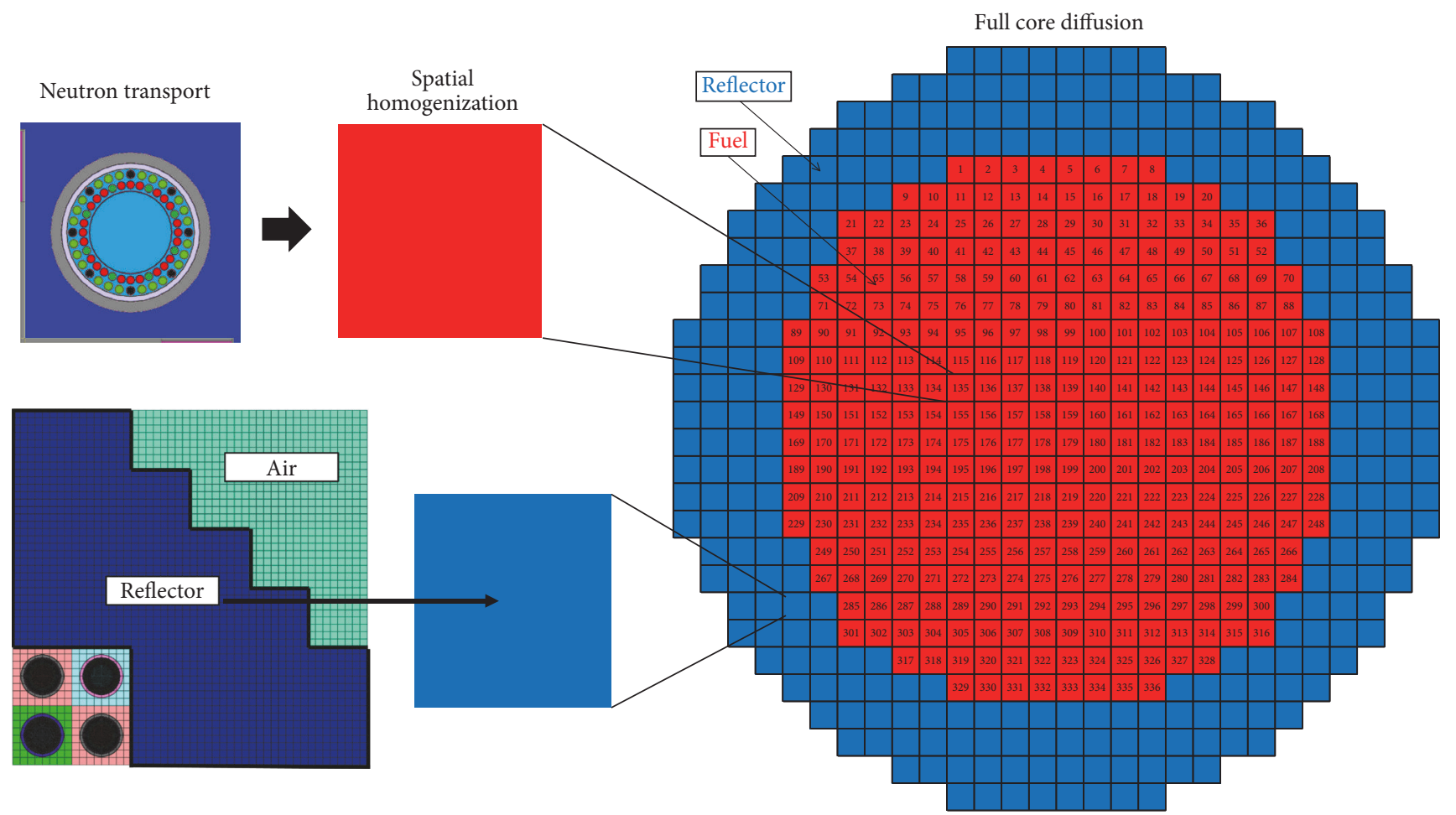

FIGURE 3: Reactor physics modelling process (2D view). 


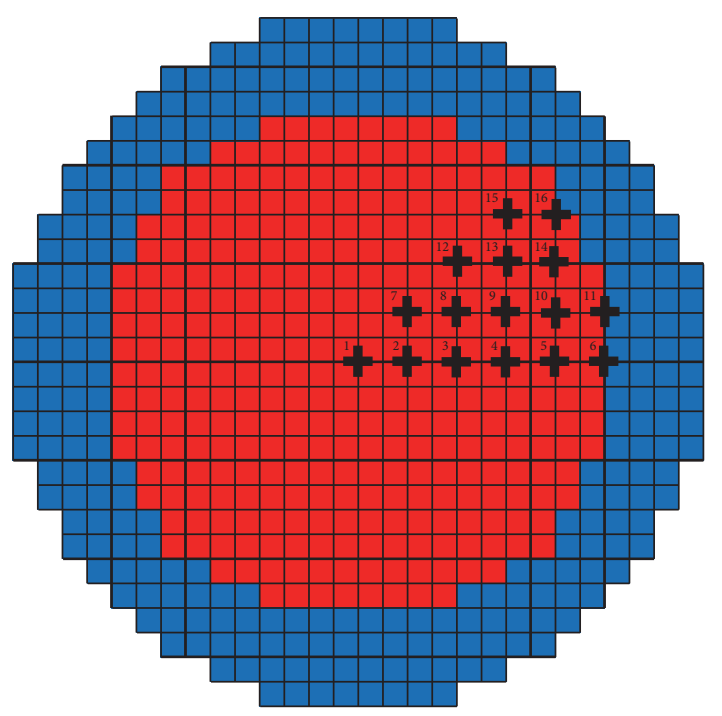

FIGURE 4: Control rods location (1/8th symmetric).

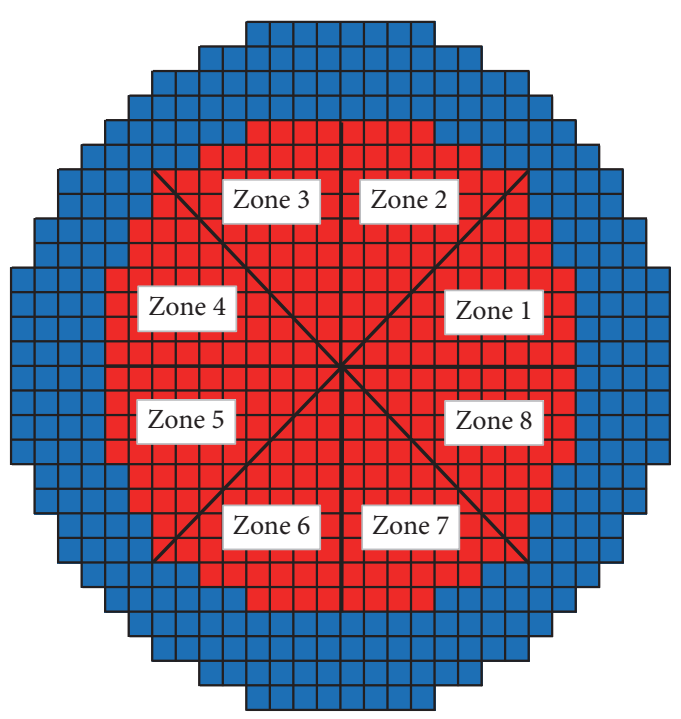

FIgURE 5: Channels splitting for RSM4.

between the two fuel rings using a constant ratio $(53 \%$ and $47 \%$ for the inner and outer ring, resp.) based on fuel lattice calculations over the fuel cycle. While this ratio varies with burnup, the values were selected such that the peak power occurs on the limiting elements and hence it is conservative for the MCST and MFCLT calculations. The power imbalance within a fuel ring due to the presence of burnable absorbers in few pins has not been considered here. As a consequence, the MFCLT is not completely conservative.

The conductivity and heat capacity for the inner ring fuel, outer ring fuel, cladding/central tube material, liners, insulator, and pressure tube were taken from [30]. This work used the Dittus-Boelter correlation for convective heat transfer; however many studies have examined that its error may be very large in the vicinity of the pseudocritical temperature. To observe the sensitivity of the MCST to the convective heat transfer coefficients three separate sensitivity studies were performed. In all sensitivity studies, a null-change transient was performed until the diffusion and thermal-hydraulic models converged to a new steady state. In the first test the convective heat transfer was reduced uniformly by $10 \%$ across the entire core and an increase of $20^{\circ} \mathrm{C}$ was observed. In the second study, the heat transfer coefficient was reduced by $50 \%$ for all RSM 4 nodes where the coolant temperature was near the pseudocritical point (where deterioration may occur) and the resultant MCST only increases by $1^{\circ} \mathrm{C}$. Finally, the conductivity and heat capacity of the fuels were increased by $10 \%$ and resulted in a $160^{\circ} \mathrm{C}$ decrease in MFCLT.

2.3. Control Rod Optimization. A genetic algorithm was used to optimize the insertion depth of the control rods during the batch cycle similar to the optimization performed in [26]. The goal was to obtain an equilibrium cycle with a nearcritical core while minimizing the MCST and the MFCLT. The simulations assume a four batch fueling scheme and a shuffling pattern and thermal-hydraulic response surface similar to [26] are used. A series of successive fuel cycles is simulated with the rod optimization performed at each burnup step in each successive fuel cycle. The iterations are terminated when the control rod pattern is constant from cycle to cycle. The insertion of the control rods at beginning of cycle (BOC) and end of cycle (EOC) for the equilibrium case is shown in Figure 7.

A coupled steady state between PARCS and RSM4 was then evaluated at BOC and EOC to obtain a consistent $3 \mathrm{D}$ power distribution with the thermal-hydraulic conditions and these coupled states are used as the initial conditions for the transients below.

2.4. PARCS/RSM4 Coupling for Transient Simulation. The synchronization in time between PARCS and RSM4 is of prime importance during a fast transient. A quasistatic process involving very small time steps was used where thermal-hydraulic conditions are assumed constant during a PARCS time step and conversely, the local powers are assumed constant during a RSM4 time step.

The neutronic simulation leads the coupling as it will initiate the reactivity transient so PARCS is first run for a small time step and the new 3D power distribution is extracted. Then, RSM4 simulations are performed for the updated 3D power distribution for the same small time step and the new 3D thermal-hydraulic conditions are extracted. In fact 8 RSM4 simulations are performed for the time step each with 46 channels so that no channel averaging is needed. The extracted powers are then used by PARCS to update all cross sections based on the partial derivatives in each branch calculation done in SCALE (see Section 2.1.1). A diagram of the coupling process is shown in Figure 8. Sensitivity simulations were performed for time steps ranging from 0.005 to $0.1 \mathrm{~s}$ with no observed impact on the conclusions.

The control rod drop accident is a localized and fast power excursion transient. Therefore, every fuel channel had to be simulated in RSM4 to obtain accurate predictions in the entire core. Channel grouping is not used in the thermalhydraulic simulations [31]. 


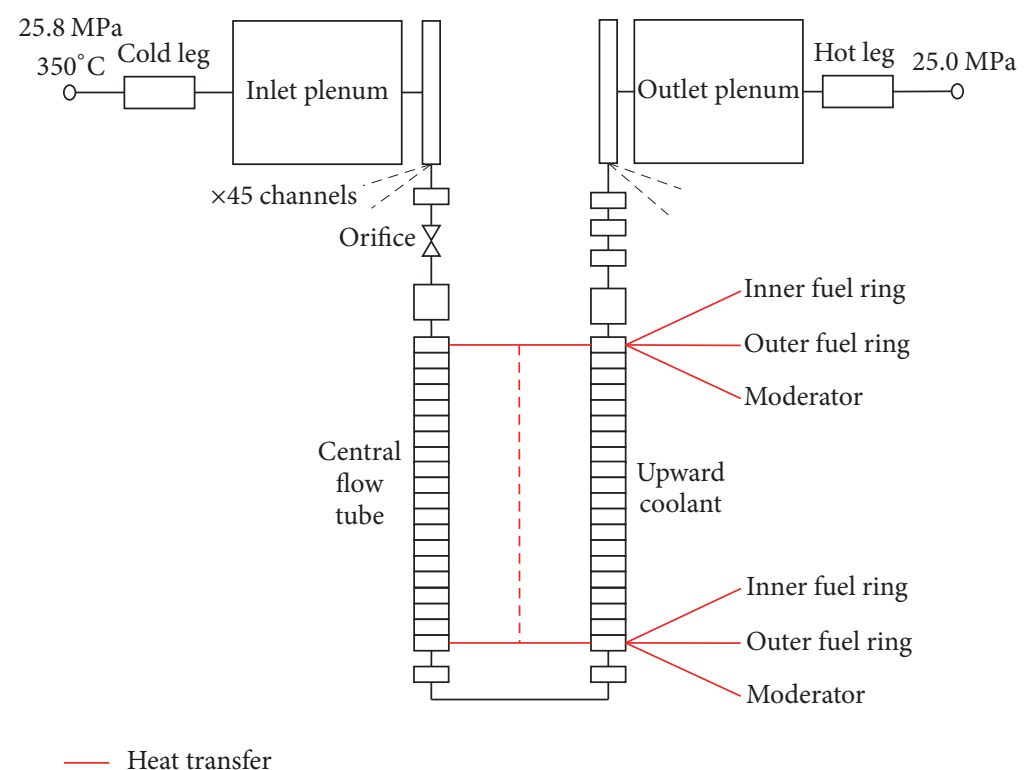

FIGURE 6: Canadian SCWR model for thermal-hydraulic studies in RELAP/SCDAPSIM/MOD4.

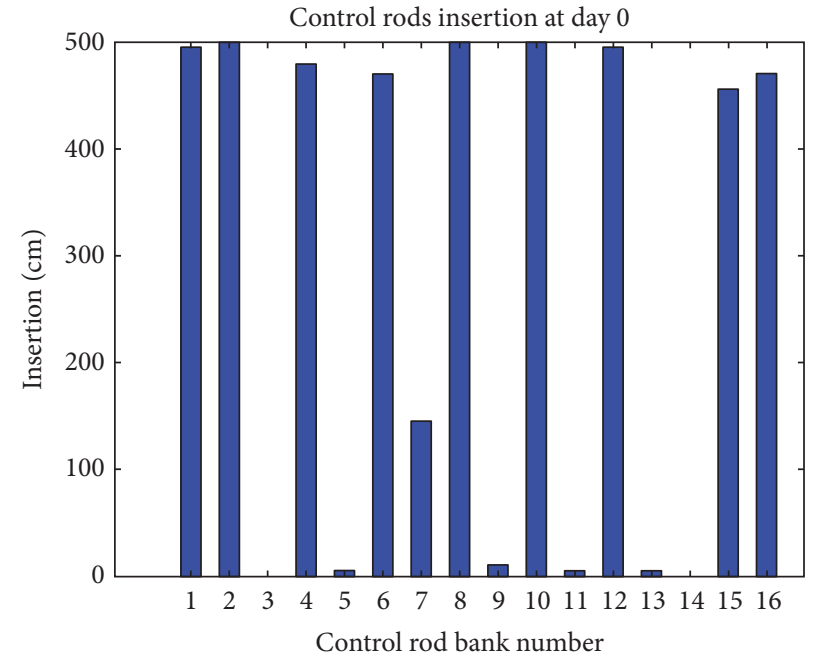

(a)

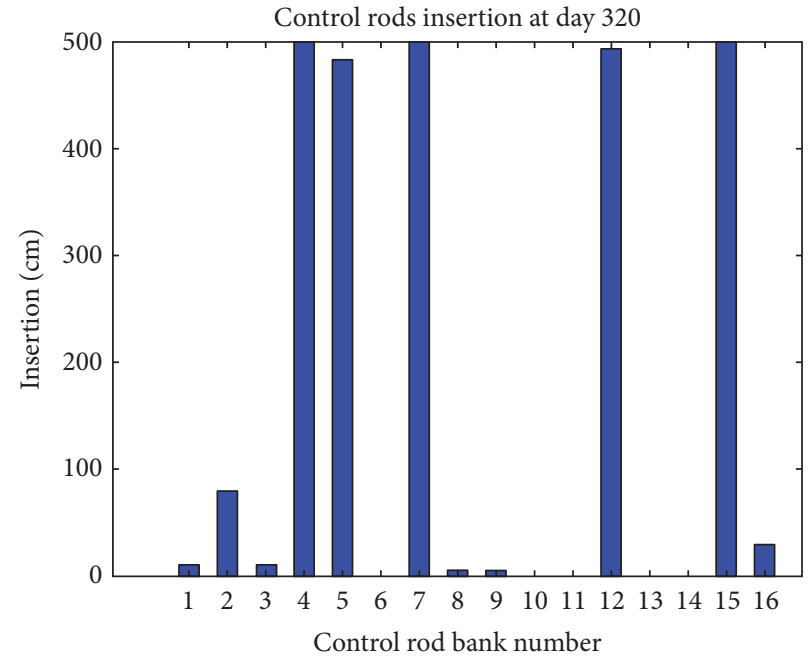

(b)

FIgURE 7: Control rods insertion at BOC (a) and EOC (b).

\section{Control Rod Drop Accident}

3.1. Transient Setup. The fully inserted, or close to full insertion, control rods at BOC and EOC have been fully removed one by one to calculate their reactivity worth (Table 4). Conversely, the control rods sitting out of the core or barely inserted have been fully inserted one by one to find to highest worth rod (bold values in Table 5). The most effective rod is assumed stuck during simulations where reactor trip is credited as per the International Atomic Energy Agency (IAEA) standards [32].

The drop time of the control rod was evaluated based on its weight and the small pressure difference between the moderator $(0.3 \mathrm{MPa})$ and the containment (atmospheric pressure of $0.1 \mathrm{MPa}$ ). The control rod's weight was calculated to be $334 \mathrm{~kg}$ based on its dimensions and material properties. The drop time was evaluated to be $0.8 \mathrm{~s}$ using Newton's second law of motion (the hydraulic resistance due to viscosity was neglected in order to provide a conservative estimate on the drop time). The sensitivity to rod drop was assessed by changing the drop time by $50 \%$.

The safety limits of interest are the integrity of the cladding $(T<1533 \mathrm{~K}[29])$ and the fuel $(T<3100 \mathrm{~K})$. The melting point of thorium-plutonium fuels can be estimated from earlier studies which evaluated the melting point of such fuels using different molar fraction ratios. Fresh fuel's melting point can be estimated to be around $3400 \mathrm{~K}$ but will likely decrease as the fuel gets irradiated [33]. Hence $3100 \mathrm{~K}$ is used as a conservative estimate of the fuel melting temperature. 
TABLE 4: Control rod reactivity worth when fully removed from the core.

\begin{tabular}{|c|c|c|c|c|c|c|c|c|c|c|c|c|c|c|}
\hline \multirow[b]{2}{*}{ Control rod number } & \multicolumn{9}{|c|}{ BOC $($ beta $=2.959 \mathrm{mk})$} & \multicolumn{5}{|c|}{ EOC $($ beta $=3.153 \mathrm{mk})$} \\
\hline & 1 & 2 & 4 & 6 & 8 & 10 & 12 & 15 & 16 & 4 & 5 & 7 & 12 & 15 \\
\hline Reactivity worth (mk) & 0.64 & 0.59 & 0.60 & 0.37 & 0.76 & 0.84 & 0.75 & 0.89 & 0.55 & 0.69 & 0.82 & 0.67 & 0.74 & 0.83 \\
\hline Reactivity worth (\$) & 0.21 & 0.20 & 0.20 & 0.12 & 0.25 & 0.28 & 0.25 & 0.30 & 0.18 & 0.23 & 0.27 & 0.22 & 0.25 & 0.28 \\
\hline
\end{tabular}

TABLE 5: Control rod reactivity worth when fully inserted into the core.

\begin{tabular}{|c|c|c|c|c|c|c|c|c|c|c|c|c|c|c|c|c|c|c|}
\hline \multirow[b]{2}{*}{$\begin{array}{l}\text { Control rod } \\
\text { number }\end{array}$} & \multicolumn{7}{|c|}{$\mathrm{BOC}(\mathrm{beta}=2.959 \mathrm{mk})$} & \multicolumn{11}{|c|}{$\mathrm{EOC}($ beta $=3.153 \mathrm{mk})$} \\
\hline & 3 & 5 & 7 & 9 & 11 & 13 & 14 & 1 & 2 & 3 & 6 & 8 & 9 & 10 & 11 & 13 & 14 & 16 \\
\hline $\begin{array}{l}\text { Reactivity } \\
\text { worth (mk) }\end{array}$ & -0.54 & -0.44 & -0.40 & -0.54 & -0.20 & -0.47 & -0.46 & -0.43 & -0.45 & -0.52 & -0.25 & -0.52 & -0.55 & -0.50 & -0.24 & -0.54 & -0.46 & -0.32 \\
\hline $\begin{array}{l}\text { Reactivity } \\
\text { worth }(\$)\end{array}$ & -0.18 & -0.15 & -0.13 & -0.18 & -0.07 & -0.16 & -0.15 & -0.14 & -0.15 & -0.17 & -0.08 & -0.17 & -0.18 & -0.17 & -0.08 & -0.18 & -0.15 & -0.11 \\
\hline
\end{tabular}

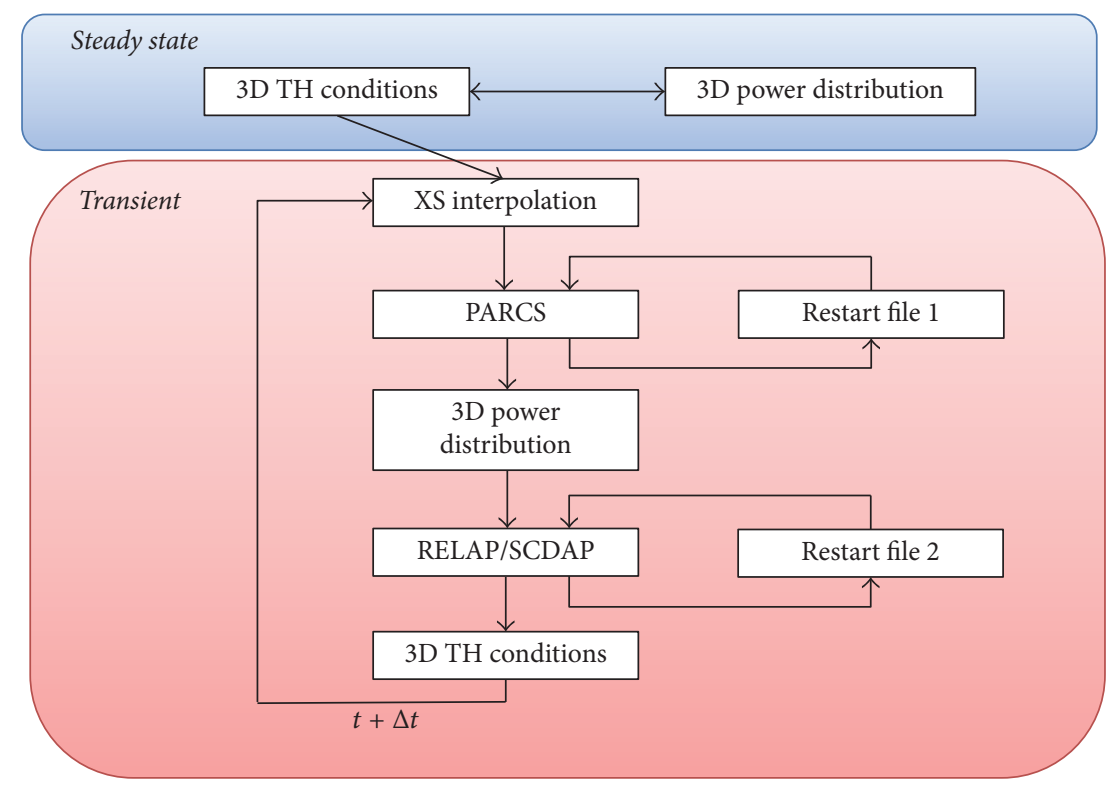

FIGURE 8: Coupling process for transient simulation.

3.2. Transients Results. A null transient was performed to ensure that the coupled initial steady-state kinetics and thermal hydraulics simulations were converged.

3.2.1. Reactivity Feedback Verification. The control rod drop accident (CRDA) of the central control rod (number 1 in Figure 4) was investigated for several cases to ensure the feedback models were properly implemented. The CRDA was first simulated without reactivity feedback and then simulated with each of the five types of reactivity feedback separately. Finally all feedback is included such that the integrated response can be assessed. Figure 9 shows the relative power change for each case.

When no reactivity feedback are modelled the prompt jump can be initially observed followed by a slow power increase which is expected as no phenomena are included to alter the power trajectory and the power will end up increasing exponentially. The impact of each reactivity feedback is then evaluated individually and they can be classified in two categories: negative feedback (fuel temperature and inner coolant density) or positive feedback (outer coolant density/temperature and the inner coolant temperature).

(i) The fuel temperature Doppler effect shows a strong negative feedback and is near-instantaneous. For the case where the fuel temperature is included as a feedback the reactor power rapidly decreases and stabilizes to approximately $2 \%$ higher than the steadystate power.

(ii) The central tube coolant density feedback also introduces a negative reactivity as shown in Figure 9 although the feedback is smaller and at a slower rate than the fuel temperature case. Here the power oscillates before converging to a power 14\% higher than the steady-state power. These oscillations are due to the heat transfer phenomena which are proceeding at a slower time scale than the initial rod perturbation. The heat generated in a fuel pin needs to be 
TABLE 6: MCST, MFCLT, and maximum relative power during the CRDA with reactor SCRAM.

(a)

\begin{tabular}{lcccccccccc}
\hline BOC & Initial & CR1 & CR2 & CR4 & CR6 & CR8 & CR10 & CR12 & CR15 & CR16 \\
\hline MCST (K) & 1119.7 & 1129.0 & 1133.7 & 1129.8 & 1334.0 & 1136.6 & 1141.6 & 1137.1 & 1149.3 & 1142.5 \\
MFCLT (K) & 2436.9 & 2516.5 & 2549.2 & 2530.0 & 3307.9 & 2570.5 & 2578.9 & 2533.5 & 2536.2 & 2512.5 \\
Max relative power & 1.0 & 1.208 & 1.194 & 1.202 & 1.121 & 1.261 & 1.321 & 1.261 & 1.344 & 1.191 \\
\hline
\end{tabular}

(b)

\begin{tabular}{lccccrr}
\hline EOC & Initial & CR4 & CR5 & CR7 & CR12 & CR15 \\
\hline MCST (K) & 1168.9 & 1187.0 & 1186.4 & 1190.8 & 1187.9 & 1185.8 \\
MFCLT (K) & 2447.8 & 2536 & 2534 & 2552 & 2535 & 2528 \\
Max relative power & 1.0 & 1.229 & 1.293 & 1.214 & 1.250 & 1.302 \\
\hline
\end{tabular}

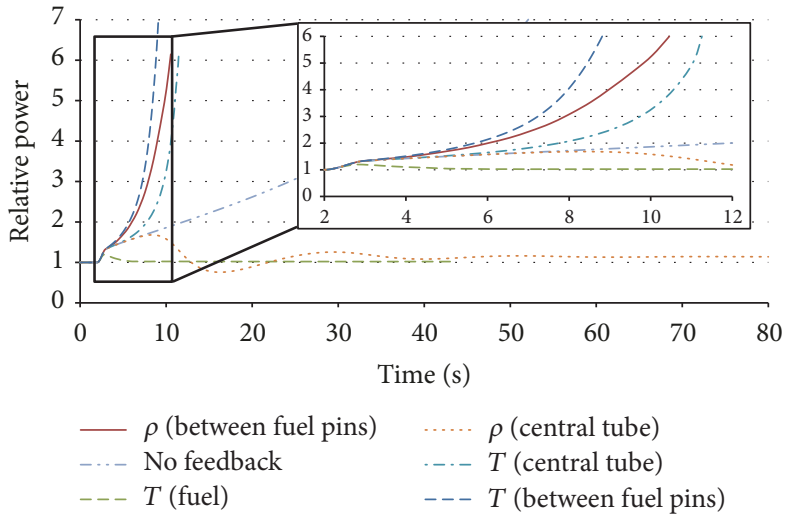

FIGURE 9: Impact of individual reactivity feedback on the power during a control rod drop accident.

transferred through the pin, the cladding, the coolant between the fuel pins, and the central tube, before finally reaching the central tube coolant and causing a perturbation. This delay causes the power transient to initially exceed its new steady-state power during the portions of the transients where power is increasing and vice versa for periods of decreasing power.

(iii) The central flow tube temperature feedback is positive as higher temperature moderators tend to up-scatter neutrons into the low-energy $\mathrm{Pu}$ fission resonances. This feedback is slightly delayed relative to the two other positive mechanisms due to the time delay involved in the heat transfer from the fuel pins through the central flow liner and to the central coolant (similar to the time delay involved in the central density feedback).

(iv) The coolant in the fuel region also has a positive feedback contribution due to its propensity to up-scatter neutrons into the low-lying $\mathrm{Pu}$ fission resonances, although the feedback has an earlier onset since the thermal lag to the coolant in this region is less than that to the central flow tube.

(v) Finally the fuel region coolant density feedback is also strongly positive and on a time scale similar to coolant temperature changes in this region of the channel.

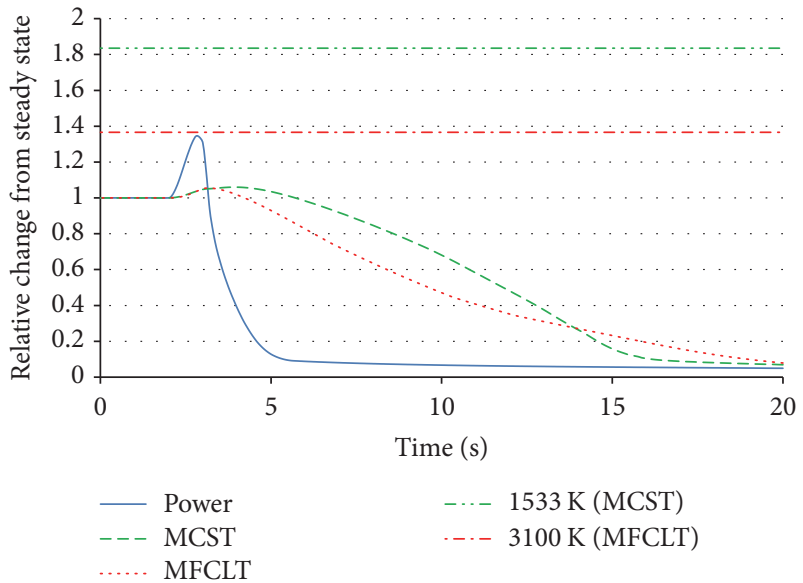

FIGURE 10: Relative power, MCST, and MFCLT evolution during the CRDA of control rod 15 .

These results are consistent with the benchmark study in [14] and confirm the proper implementation of the reactivity feedback.

3.2.2. CRDA with SCRAM. All the fully inserted, or near full insertion, control rods were considered for rod drop analyses at both BOC and EOC (Table 6). A minimum time step of $0.1 \mathrm{~s}$ (maximum time step of $0.5 \mathrm{~s}$ ) was used during these transients based on a parametric study presented below (Table 7). Each control rod starts dropping two seconds after the beginning of the simulation from its initial position and is removed until the out-of-the-core position in $0.8 \mathrm{~s}$ (simulation time reaching $2.8 \mathrm{~s}$ ) by assuming a constant speed fall. The reactor trip signal occurs when the total power reaches $115 \%$ full power (FP) and the reactor SCRAM delay is $0.6 \mathrm{~s}$, consistent with LWR studies $[34,35]$. During the reactor SCRAM, all the control rods (no shutoff rods were modelled) are linearly inserted into the core in $3 \mathrm{~s}$ (approximately speed of $1.6 \mathrm{~m} / \mathrm{s}$ ) with the exception of the rod dropped and the assumed unavailable rod (the most effective rod). A typical transient for the changes in relative power, MCST, and MFCLT as a function of time for the drop of control rod 15 at BOC have been plotted in Figure 10. Note that the MCST 
TABLE 7: Parametric study on the CRDA of control rod 15 at BOC.

\begin{tabular}{|c|c|c|c|c|c|c|c|}
\hline CR15 at BOC & Time step (s) & Scram signal (\% FP) & Scram delay (s) & Drop time (s) & Max relative power & $\operatorname{MCST}(\mathrm{K})$ & MFCLT (K) \\
\hline Case 0: reference & 0.02 & 115 & 0.6 & 0.8 & 1.332 & 1148.7 & 2535.6 \\
\hline Case 1: time step decrease & 0.005 & 115 & 0.6 & 0.8 & 1.331 & 1147.6 & 2533.1 \\
\hline Case 2: scram signal & 0.02 & 120 & 0.6 & 0.8 & 1.332 & 1152.4 & 2544.4 \\
\hline Case 3: scram delay & 0.02 & 115 & 1.2 & 0.8 & 1.332 & 1173.2 & 2587.5 \\
\hline Case 4: drop time & 0.02 & 115 & 0.6 & 0.4 & 1.3893 & 1148.4 & 2540.1 \\
\hline Case 5: time step increase & 0.1 & 115 & 0.6 & 0.8 & 1.344 & 1149.3 & 2536.2 \\
\hline
\end{tabular}

A B C D E F GH I J K L M N O P Q R S T

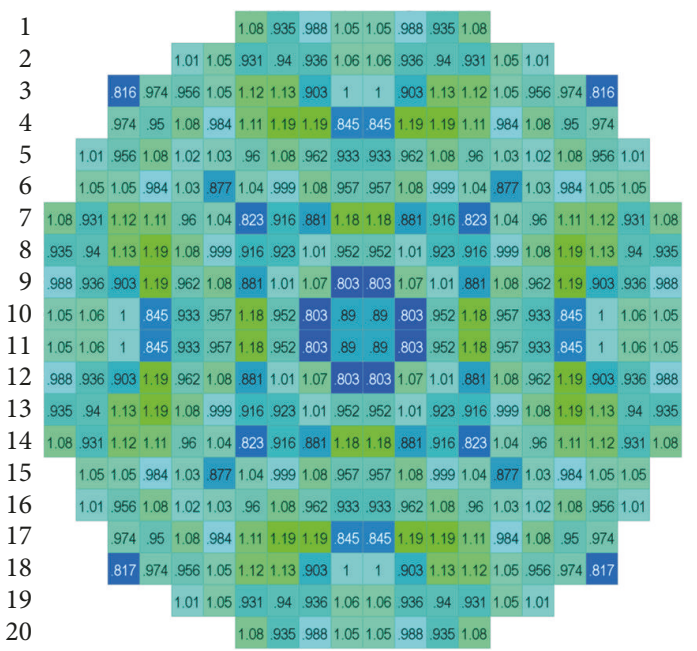

(a)
A B C D E F G H I J K L MN O P Q R S T
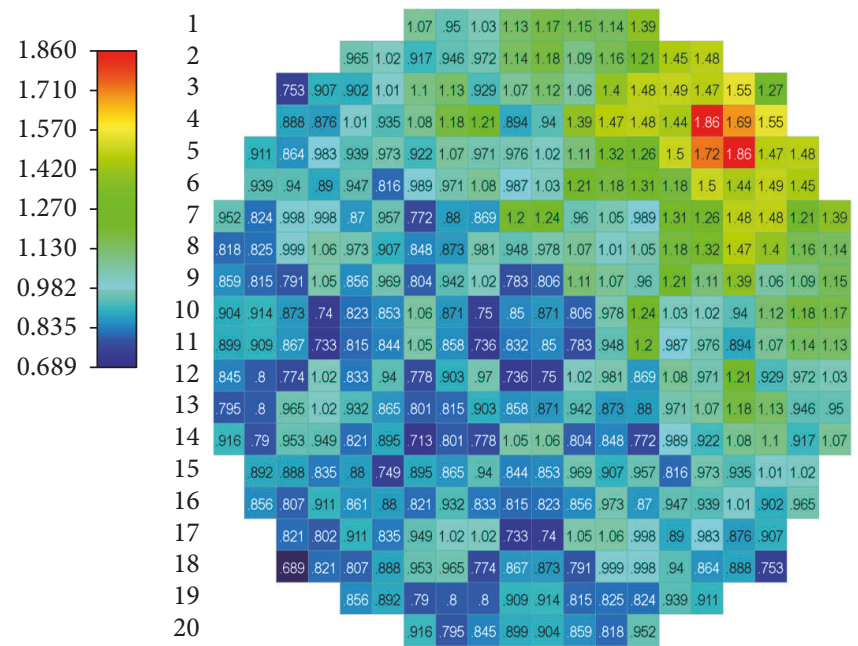

(b)

FIGURE 11: Normalized assembly power distribution before the accident (a) and at core maximum power (b) during the CRDA of control rod 15.

and MFCLT were normalized relative to the hot zero power condition $(623 \mathrm{~K})$ and slowly converge towards it as the power converges to zero. The normalized radial power distribution has also been plotted before the accident and when the core reaches its maximum power ( $0.8 \mathrm{~s}$ after the beginning of the drop) (Figure 11). The local power excursion near the dropped control rod can be clearly observed with the relative assembly power going from 1.08 up to 1.86 for assembly number 50 (see Figure 3 for assembly numeration). Figure 12 is an axial cut of row 4 at four different times during the transient. At $2.4 \mathrm{~s}$, half of the control rod is still inserted into the core leading to a distorted power distribution towards the top of the core, especially where the control rod is removed (column $\mathrm{P}$ and Q). It can be noted that the normalized power remains locally high after the SCRAM $(t=10 \mathrm{~s})$ because the dropped rod and the most effective rod are assumed stuck; however, the core total power is significantly reduced with the SCRAM $(6.7 \%$ FP). Figure 13 shows an axial cut of row 4 for the cladding and fuel centerline temperature at steady state and when they reach their highest value. A slight increase and asymmetry can be observed.
At BOC condition a CRDA involving control rod number 6 never reaches the overpower signal of $115 \%$ full power. Therefore, the reactor trip does not register and the core reaches a new steady state with excessively high cladding and fuel temperature. Further analysis of such cases is provided in the next section which considers cases where reactor trip is unavailable.

For all other CRDA cases the safety limits were met. The maximum reactivity insertion was $0.3 \$$ (see Table 4); therefore supercriticality is avoided. The power excursion can be terminated by the reactivity feedback alone but the reactor SCRAM safely shut down the reactor and limits the MCST increase to $10-30^{\circ} \mathrm{C}$ and the MFCLT rise to $80-150^{\circ} \mathrm{C}$.

Parametric studies on the minimum time step, control rod drop time, overpower signal, and SCRAM delay were carried out to evaluate the sensitivity of the results to those parameters. The CRDA for control rod 15 at BOC was simulated with the modified parameters and the results are shown in Table 7.

Cases 0,1 , and 5 demonstrate the minimal impact of the time step on the studied parameters. A higher time step 


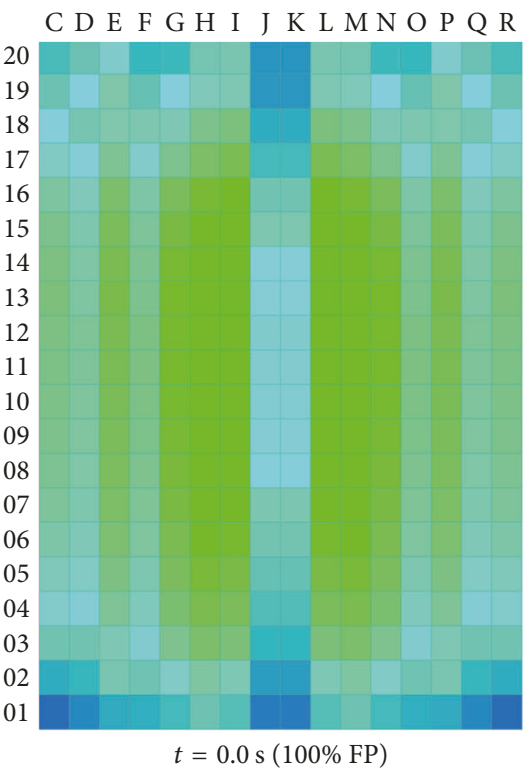

C D E F G H I J K L MNOP Q R

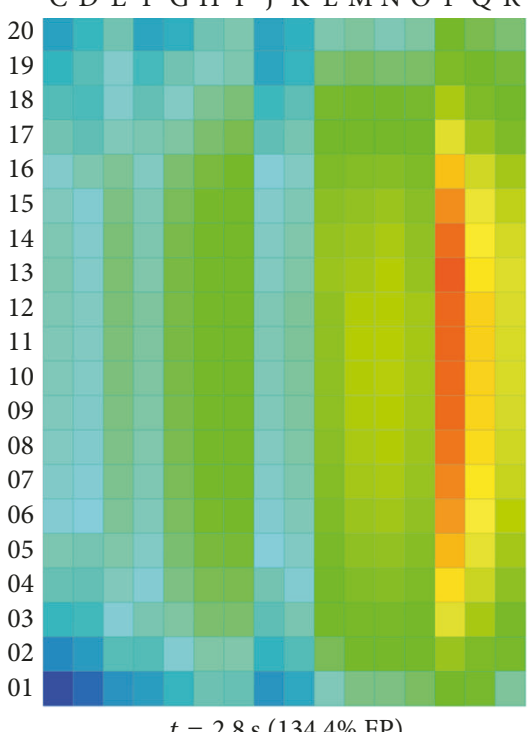

$t=2.8 \mathrm{~s}(134.4 \% \mathrm{FP})$
C D E F G H I J K L MNO P Q R

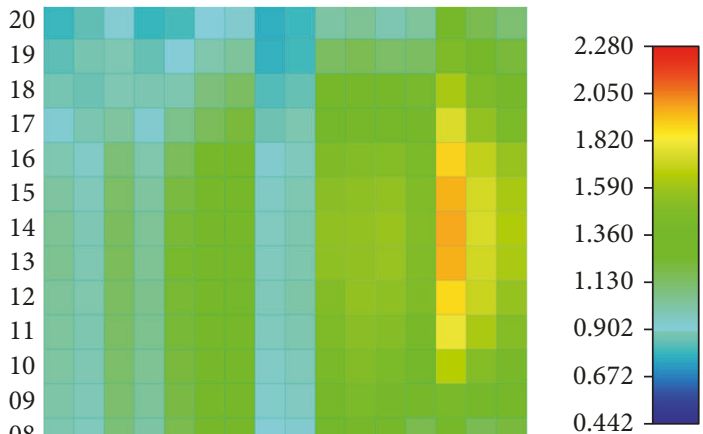

C D E F G H I J K L MN O P Q R

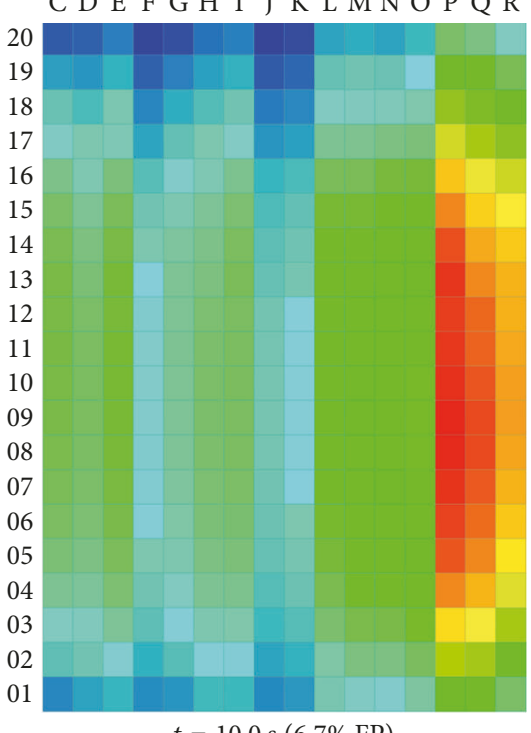

$t=10.0 \mathrm{~s}(6.7 \% \mathrm{FP})$

FIGURE 12: Snapshots of the axial power distribution of row 4 for the CRDA of CR15 with reactor SCRAM.

tends to overestimate the MCST, MFCLT, and maximum power albeit only to a small extent. Therefore any time step between $0.005 \mathrm{~s}$ and $0.1 \mathrm{~s}$ is considered acceptable. Increasing the SCRAM signal from $115 \%$ to $120 \%$ full power also has negligible effects on the transient. The MCST and MFCLT are more sensitive to the time delay associated with the SCRAM signal, but they remain far below the safety limits. Finally, the sensitivity to rod drop timing was examined by decreasing the drop time by $50 \%$ and showed that the power increase is more substantial but the MCST and MFCLT are not significantly affected.

3.2.3. CRDA without SCRAM. The CRDAs discussed above were reexamined assuming a rod drop without SCRAM. Such events involve changes in power, fuel temperature, coolant properties, and so on over the full core. In all cases the power was redistributed within the core and a new steadystate power was reached. The MCST and MFCLT were evaluated to assess the performance of the core and the results summarized in Table 8. For almost all cases the fuel centerline limit was exceeded; hence reactor SCRAM is required for this accident scenario.

The relative core power, MCST, and MFCLT change for the drop of control rod 15 at BOC are presented in Figure 14. This scenario presents the highest cladding temperature increase as well as the highest power increase.

The normalized radial power distribution has been plotted for three states: before the accident $(0 \mathrm{~s})$, at maximum 


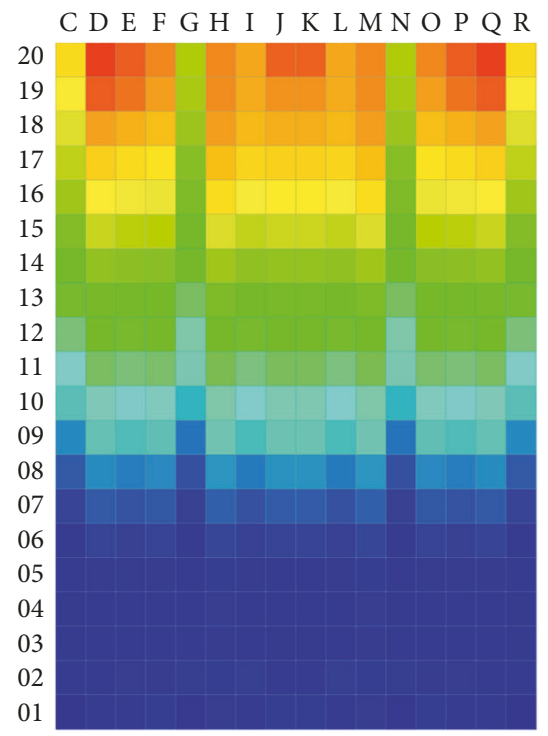

Cladding temperature $t=0.0 \mathrm{~s}$

C D E F G H I J K L MNOP Q R

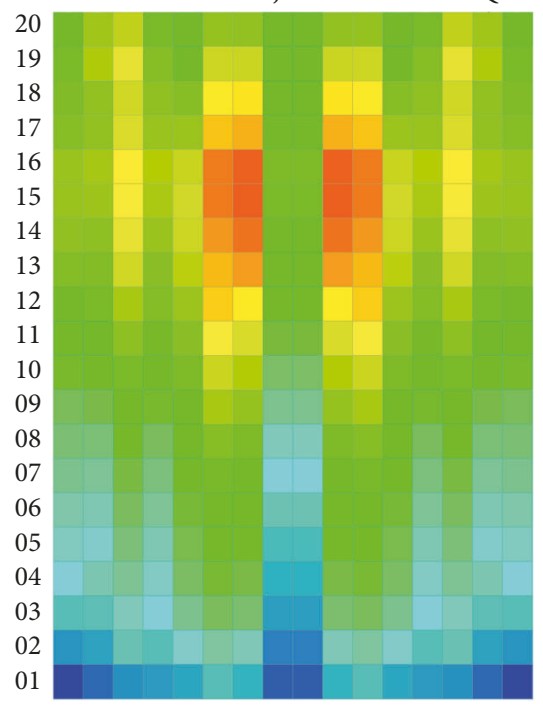

Fuel centerline temperature $t=0.0 \mathrm{~s}$
C D E F G H I K L MNOP Q R

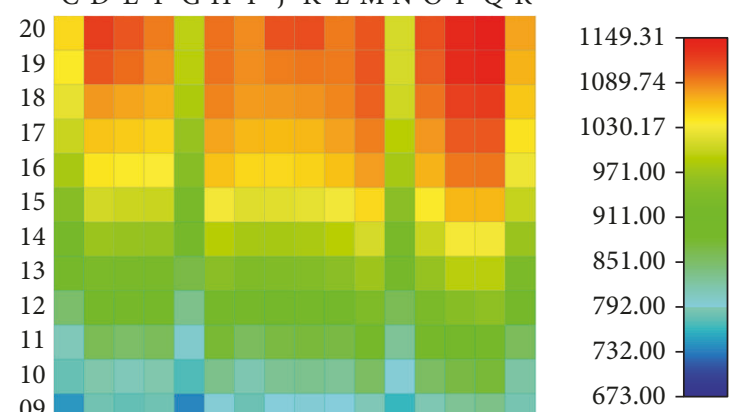

Cladding temperature $t=3.9 \mathrm{~s}$

C D E F GH I J K L MNOP Q R

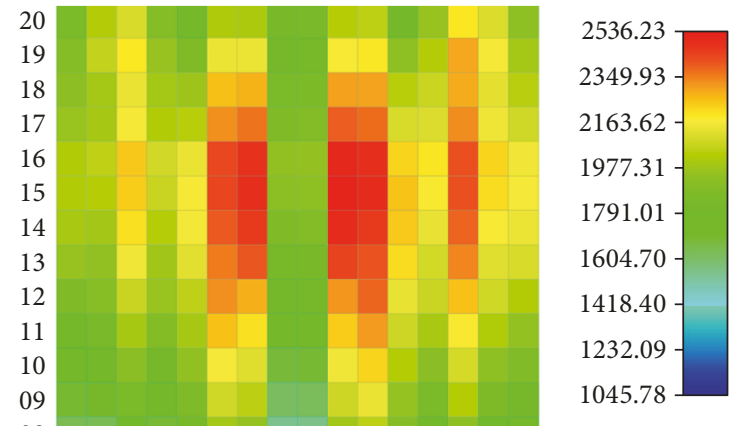

Fuel centerline temperature $t=3.2 \mathrm{~s}$

FIGURE 13: Snapshots of the cladding and fuel centerline temperature for the CRDA of CR15 with reactor SCRAM.

core power (2.8 s), and when the MFCLT reached the melting point of $3100 \mathrm{~K}$ (9.1 s). As the two first states are identical to the transient without SCRAM they are not plotted here again and only the latter state is shown in Figure 15. After reaching a maximum at $2.8 \mathrm{~s}$, the radial power tilt decreases due to the reactivity feedback. For instance, the relative assembly power in assembly 50 increases from 1.08 to 1.86 before decreasing to 1.61 .

A vertical slice of row 4 of the core was used to plot the normalized axial power distribution at 4 specific times of the transient (Figure 16): before the accident $(0 \mathrm{~s})$, half-way through the rod drop (2.4 s), rod reaching the out-of-the-core position (2.8 s), and when the MFCLT reached the assumed melting point (9.1 s). The cladding and fuel centerline temperature were also plotted before the transient and at $9.1 \mathrm{~s}$. The power decreases after the positive reactivity insertion due to the negative power coefficient and stabilizes to a new level (104\% FP in this case).

Initially, the MCST is located in this vertical slice (column $\mathrm{Q}$ in Figure 17 or assembly 51) but the MFCLT is in assembly 163. The MCST remains in the same location as the transient progresses because the MCST is already located around the failing rod. However, the MFCLT location changes to assembly 50 (column P in Figure 17) two seconds after the initiation of the transient. 
TABLE 8: Results for CRDAs without SCRAM.

(a)

\begin{tabular}{|c|c|c|c|c|c|c|c|c|c|c|}
\hline BOC & Initial & CR1 & CR2 & CR4 & CR6 & CR8 & CR10 & CR12 & CR15 & CR16 \\
\hline $\operatorname{MCST}(\mathrm{K})$ & 1119.7 & 1363 & 1358 & 1369 & 1333 & 1397 & 1450 & 1411 & 1493 & 1431 \\
\hline $\operatorname{MFCLT}(\mathrm{K})$ & 2436.9 & 2855 & 3139 & 3097 & 3307 & 3478 & 3787 & 3379 & 3735 & 3577 \\
\hline Max relative power & 1.0 & 1.203 & 1.189 & 1.198 & 1.119 & 1.255 & 1.312 & 1.256 & 1.333 & 1.189 \\
\hline New relative steady-state power & - & 1.031 & 1.030 & 1.029 & 1.018 & 1.035 & 1.034 & 1.034 & 1.033 & 1.024 \\
\hline
\end{tabular}

(b)

\begin{tabular}{lccccrr}
\hline EOC & Initial & CR4 & CR5 & CR7 & CR12 & CR15 \\
\hline MCST (K) & 1168.9 & 1429 & 1450 & 1364 & 1400 & 1458 \\
MFCLT (K) & 2447.8 & 3233 & 3400 & 3122 & 3100 & 3350 \\
Max relative power & 1.0 & 1.223 & 1.285 & 1.209 & 1.243 \\
New relative steady-state power & - & 1.037 & 1.037 & 1.037 & 1.038 & 1.038 \\
\hline
\end{tabular}

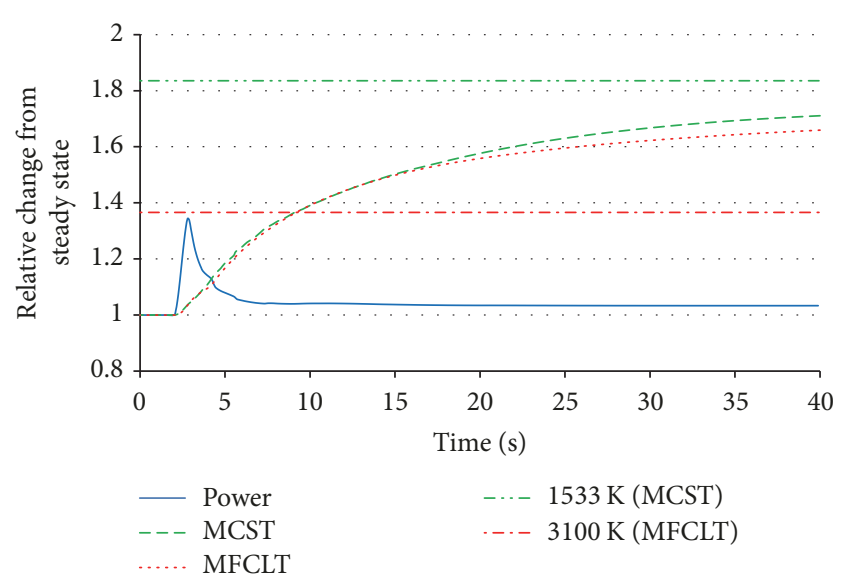

FIGURE 14: Normalized power, MCST, and MFCLT evolution during control rod 15 drop without SCRAM.

\section{Conclusion}

A system capable of simulating coupled neutron physics and thermal-hydraulic transients for the Canadian Supercritical Water-cooled Reactor has been developed with PARCS, RELAP/SCDAPSIM/MOD4, and external python scripts for data exchange. Control rod drop accidents have not previously been assessed for this core design and given the fact these accidents are localized, fast, and asymmetric, there is a need for fully coupled 3D neutron kinetic and thermalhydraulic analysis. The PARCS spatial kinetics model was built using the cross sections and kinetics parameters evaluated as function of burnup and axial elevation at the lattice level and the RSM4 model includes all of the 336 fuel assemblies.

Five types of feedback were considered in addition to the effect of the rod drop. In order to verify the coupled model a series of separate effect feedback analyses were performed where each piece of feedback was considered in isolation. The

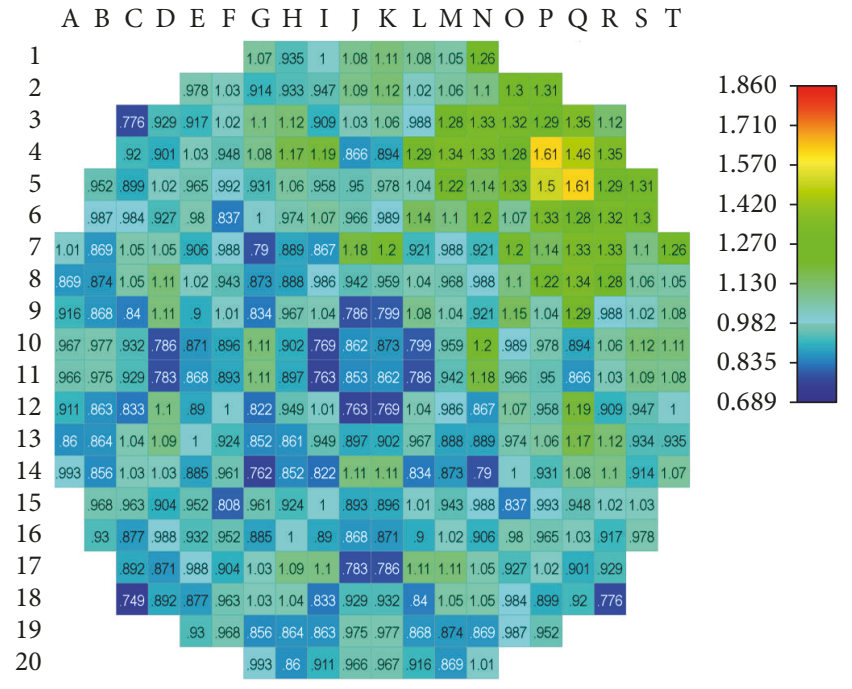

FIGURE 15: Normalized radial power distribution reached at $t=9.1 \mathrm{~s}$ without SCRAM.

strong fuel Doppler effect was found to be very stabilizing and quickly terminated the transient. The coolant density in the central tube also limits the power excursion but oscillations were observed due to the differences between neutronic and heat transfer time scales. While the three other pieces of feedback are positive, the power coefficient remains strongly negative.

The reactivity worth of each rod was evaluated at BOC and EOC when dropped. Even though the delayed neutron fraction is low (beta $\sim 0.3 \%$ ) due to the high plutonium content, the reactivity insertion remains less than prompt criticality for all drop scenarios. The first set of transients assumed an operational reactor trip when the core power exceeded $115 \%$ full power. After a delay of 0.6 second, all the control rods except the failed one and the highest 

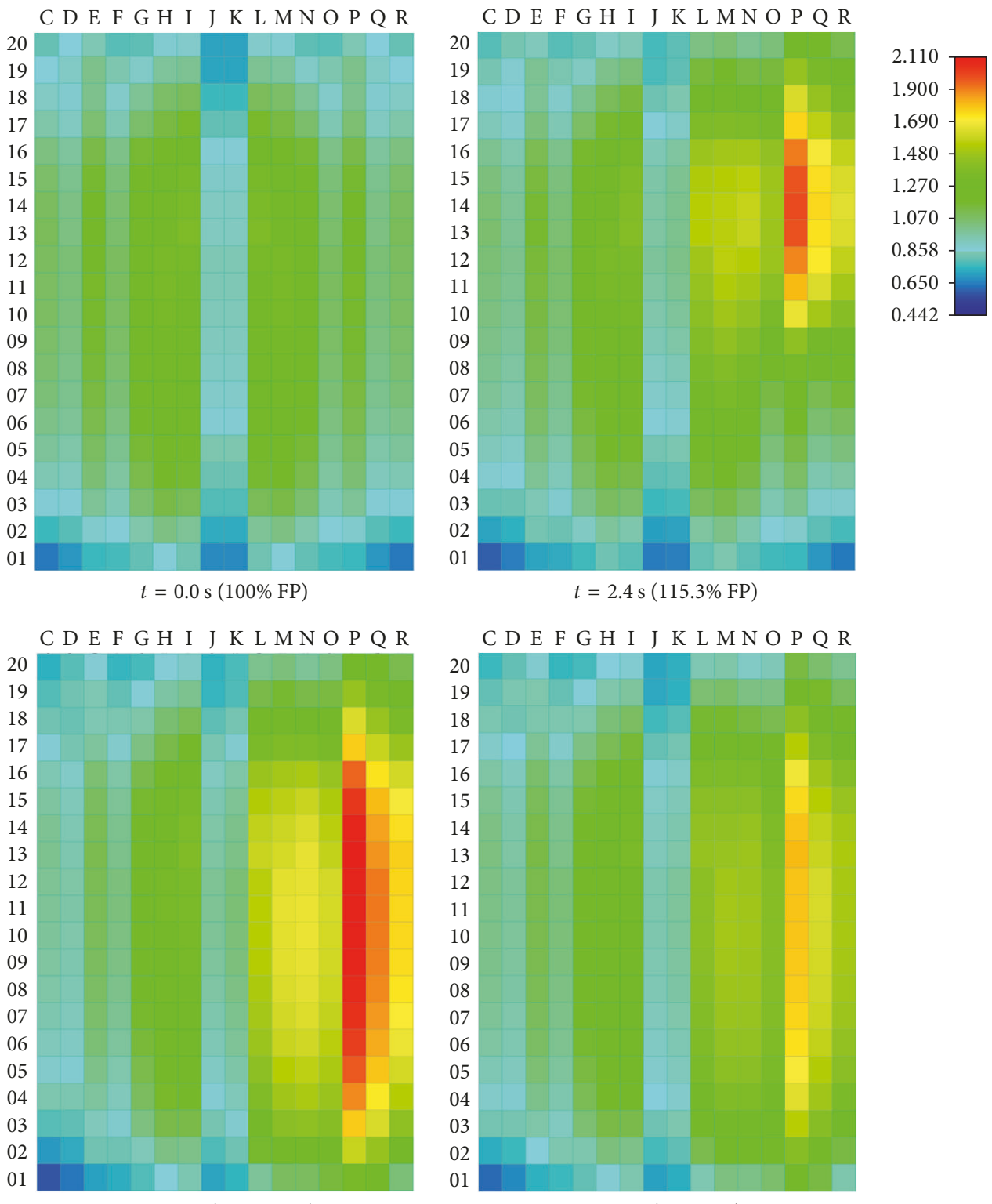

FIGURE 16: Snapshots of the normalized axial power distribution of row 4 during the CRDA of CR15 without reactor SCRAM.

reactivity worth rod were introduced from their current position to a fully inserted position using a conservative insertion characteristic time. All transients but one activated the reactor trip and safely shutdown without challenging the safety margins. Moreover, a parametric study was carried out on the minimum time step, overpower trip set point, SCRAM delay, and control rod drop time. The maximum relative power, MCST, and MFCLT were found to be fairly insensitive to those parameters. However, while the case which did not trip reached a new steady state and the MCST remained below the safety limit, fuel melting occurred in the assemblies around the dropped rod. As a consequence, other detection techniques and trip parameters are needed. For example, the local Neutron Power Protection (NOP) system utilized in the existing CANDU fleet could be considered for this design.

While unacceptable from a consequence standpoint (i.e., fuel melting), cases without reactor SCRAM are interesting to assess the overall core properties. The study shows that almost all the transients reached a MFCLT above $3100 \mathrm{~K}$; therefore, fuel melting would occur in most cases and show the necessity for reactor SCRAM demonstrating the need for special safety system action for these events.

\section{Conflicts of Interest}

The authors declare that there are no conflicts of interest regarding the publication of this paper 


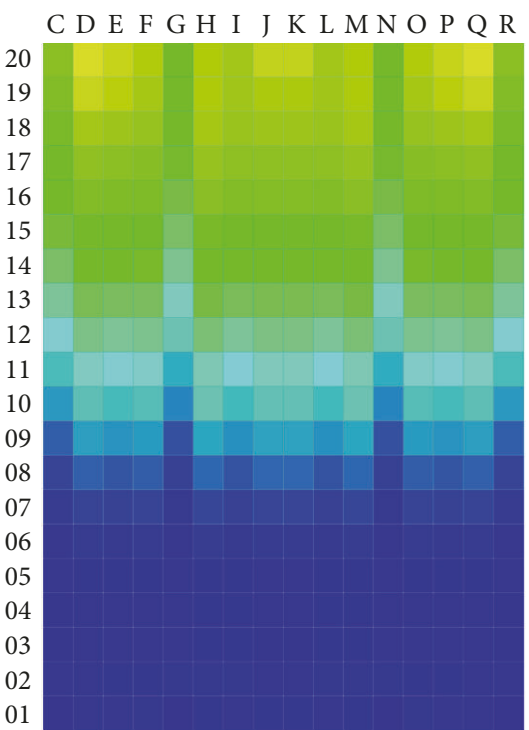

Cladding temperature $t=0.0 \mathrm{~s}$

C D E F G H I J K L MN O P Q R

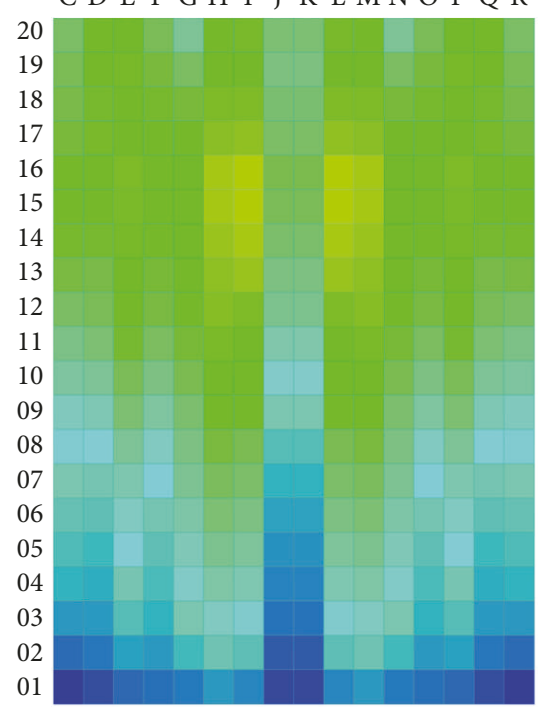

Fuel centerline temperature $t=0.0 \mathrm{~s}$
C D E F G H I J K L MN O P Q R

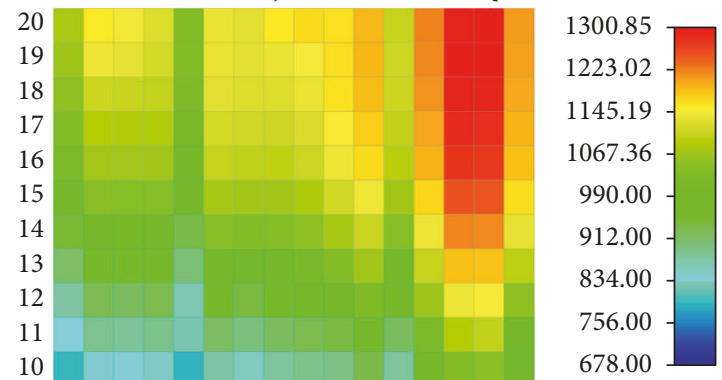

Cladding temperature $t=9.1 \mathrm{~s}$

(a)

C D E F G H I K L MNO P Q R

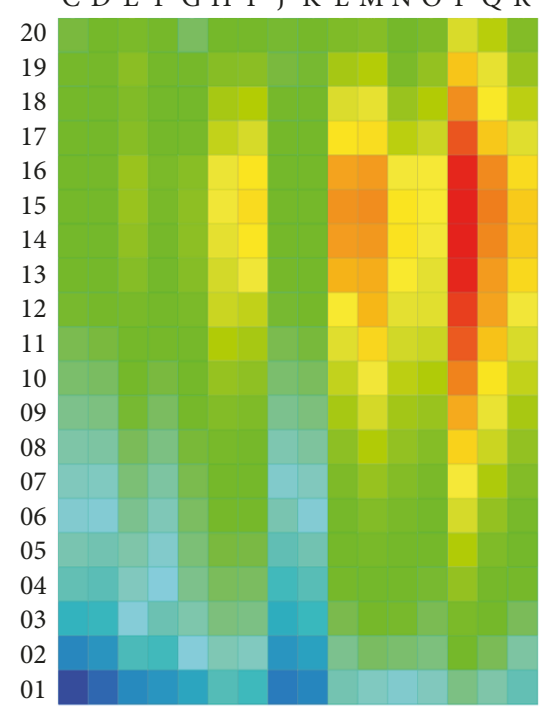

Fuel centerline temperature $t=9.1 \mathrm{~s}$

(b)

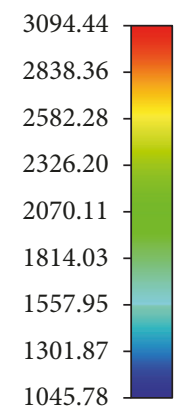

1045.78

FIGURE 17: Snapshot of the cladding (a) and fuel centerline (b) temperature of row 4 during the CRDA of CR15 without reactor SCRAM.

\section{Acknowledgments}

The authors would like to thank Andrew Ward from the University of Michigan for his help regarding PARCS. This work was funded by Natural Resources Canada (NRCAN) through the Office of Energy Research and Development, Canadian Nuclear Laboratories (CNL), and Natural Sciences and Engineering Research Council of Canada (NSERC).

\section{References}

[1] L. K. H. Leung, M. Yetisir, W. Diamond et al., "A next generation heavy water nuclear reactor with supercritical water as coolant," in Proceedings of the International Conference on Future of Heavy Water Reactors, Ottawa, Canada, 2011.

[2] F. Salaun and D. Novog, "Spatial and bulk reactivity systems design and optimization for the Canadian Supercritical Water Reactor," Canadian Nuclear Laboratories Nuclear Review, vol. 5, no. 2, pp. 285-298, 2016.

[3] M. Andreani, D. Bittermann, P. Marsault et al., "Evaluation of a preliminary safety concept for the HPLWR," Progress in Nuclear Energy, vol. 55, pp. 68-77, 2012.

[4] C. Maráczy, A. Keresztúri, I. Trosztel, and G. Hegyi, "Safety analysis of reactivity initiated accidents in a HPLWR reactor by the coupled ATHLET-KIKO3D code," Progress in Nuclear Energy, vol. 52, no. 2, pp. 190-196, 2010. 
[5] G. Hegyi, A. Kereszturi, C. Maraczy, and I. I. Trosztel, "reactivity initiated accident analysis of the HPLWR Three pass core with ascending gap flow using the KIKO3D-ATHLET code," in Proceedings of the International Conference Nuclear Energy for New Europe, Portoroz, Sloven, 2010.

[6] C. J. Jeong and H. Choi, "Xenon transient analysis for direct use of spent pressurized water reactor fuel in CANDU reactors (DUPIC)," Annals of Nuclear Energy, vol. 27, no. 3, pp. 269-278, 2000.

[7] T. Reiss, S. Fehér, and S. Czifrus, "Xenon oscillation in SCWRs," Progress in Nuclear Energy, vol. 53, no. 5, pp. 457-462, 2011.

[8] Y. Ishiwatari, K. Silva, Z. Xiong, S. Sakurai, and R. Hamazaki, "Safety analysis of JSCWR," in Proceedings of the in The 5th International Symposium on Supercritical Water Reactor (ISSCWR-5, Vancouver, Canada, March 2011.

[9] N. Tamiya, Sutanto, and Y. Oka, "Safety analysis of a Super LWR with double tube water rods," Nuclear Engineering and Design, vol. 266, pp. 129-136, 2014.

[10] X. Cheng, X.-J. Liu, and Y.-H. Yang, "A mixed core for supercritical water-cooled reactors," Nuclear Engineering and Technology, vol. 40, no. 2, pp. 117-126, 2008.

[11] Z. Xu, D. Hou, S. Fu, Y. Yang, and X. Cheng, "Loss of flow accident and its mitigation measures for nuclear systems with SCWR-M," Annals of Nuclear Energy, vol. 38, no. 12, pp. 26342644, 2011.

[12] X. J. Liu, S. W. Fu, Z. H. Xu, Y. H. Yang, and X. Cheng, "LOCA analysis of SCWR-M with passive safety system," Nuclear Engineering and Design, vol. 259, pp. 187-197, 2013.

[13] P. Schwanke and E. Nichita, "Preliminary space-kinetics simulation of a coolant voiding-induced transient for a supercritical water cooled reactor with re-entrant fuel channels," in Proceedings of the in The 19th Pacific Basin Nuclear Conference (PBNC, 2014), Vancouver, Canada, 2014.

[14] J. Sharpe, F. Salaun, D. Hummel et al., "A Benchmark Comparison of the Canadian Supercritical Water-cooled Reactor (SCWR) 64-element Fuel Lattice Cell Parameters Using Various Computer Codes," in Proceedings of the The 35th Annual Canadian Nuclear Society Conference, pp. 422-441, Saint John, Canada, June 2015.

[15] D. W. Hummel and D. R. Novog, "Coupled 3D neutron kinetics and thermalhydraulic characteristics of the Canadian supercritical water reactor," Nuclear Engineering and Design, vol. 298, pp. 78-89, 2016.

[16] P. Wu, J. Shan, J. Gou, L. K. H. Leung, B. Zhang, and B. Zhang, "Heat transfer effectiveness for cooling of Canadian SCWR fuel assembly under the LOCA/LOECC scenario," Annals of Nuclear Energy, vol. 81, pp. 306-319, 2015.

[17] C. Shih, A. Ho, J. Wang, H. Lin, and S. Chiang, Analysis of the Control Rod Drop Accident (CRDA) for Lungmen ABWR, US Nuclear Regulatory Commission, Washington, DC, USA.

[18] P. Adouki and G. Marleau, "Neutronics/Thermalhydraulics coupling in a CANDU SCWR," in Proceedings of the The $3 \mathrm{rd}$ China-Canada Joint Workshop on Supercritical Water-Cooled Reactors, CCSC-2012, Xian, China, 2012.

[19] M. Hursin and T. Downar, "PWR control rod ejection analysis with MOC code DeCART," in Proceedings of the Joint International Workshop: Nuclear Technology and Society, Berkeley, Calif, USA, 2008.

[20] H. S. Cheng and D. J. Diamond, "Analyzing the rod drop accident in a boiling water reactor," Nuclear Technology, vol. 56, no. 1, pp. 40-54, 1982.
[21] T. Downar, Y. Xu, and V. Seker, PARCS v3.0 U.S. NRC Core Neutronics Simulator, USER MANUAL Draft, 2013.

[22] C. M. Allison and J. K. Hohorst, "Role of RELAP/SCDAPSIM in nuclear safety," Science and Technology of Nuclear Installations, vol. 2010, Article ID 425658, 17 pages, 2010.

[23] SCALE: A Comprehensive Modelling and Simulation Suite for Nuclear Safety Analysis and Design, Oak Ridge National Laboratory, 2011.

[24] J. Duderstadt and L. Hamilton, Nuclear Reactor Analysis, John Wiley Sons, Mississauga, Canada, 1976.

[25] L. Massimo, Physics of High Temperature Reactors, Pergamon Press, New York, NY, USA, 1976.

[26] F. Salaun and D. Novog, "Optimization of the canadian scwr core using coupled 3D reactor physics and thermalhyraulics calculations," Journal of Nuclear Engineering and Radiation Science, 2017.

[27] J. Pencer, M. McDonald, and V. Anghel, "Parameters for transient response modeling for the Canadian SCWR," in Proceedings of the The 19th Pacific Basin Nuclear Conference (PBNC-2014), Vancouver, Canada, 2014.

[28] A. Godfrey and R. Lee, VERAview User's Guide. CASL-U2016-1058-000, Oak Ridge National Laboratory, Oak Ridge, Tennessee, 2016

[29] C. Lou, Loss of Coolant Accident Simulation for the Canadian Supercritical Water-Cooled Reactor Using RELAP5/MOD4, McMaster University, Hamilton, Canada, 2016.

[30] D. Hummel, Transient neutronic-thermalhydraulic coupling in a PT-SCWR [Ph.D. thesis], McMaster University, Hamilton, Canada, 2015.

[31] T. Barrachina, M. Garcia-Fenoll, F. Ánchel et al., "REA 3Ddynamic analysis in Almaraz NPP with RELAP5/PARCS v2.7 and SIMTAB cross-sections tables," Progress in Nuclear Energy, vol. 53, no. 8, pp. 1167-1180, 2011.

[32] C. B. E. Allison, F. D’Auria, M. Jankowski et al., Accident Analysis for Nuclear Power Plants with Pressurized Water Reactors, International Atomic Energy Agency, 1999.

[33] P. S. Ghosh, N. Kuganathan, C. O. T. Galvin et al., "Melting behavior of (Th, U)O2 and (Th,Pu)O2 mixed oxides," Journal of Nuclear Materials, vol. 479, pp. 112-122, 2016.

[34] D. Diamond, B. Bromley, and A. Aronson, Studies of the rod ejection accident in a PWR, Brookhaven National Laboratory, New-York, 2002.

[35] T. Barrachina, R. Miró, G. Verdú, A. Ortego, and J. C. MartínezMurillo, "Rod ejection accident 3D-dynamic analysis in trillo NPP with RELAP5/PARCS V2.7," in Proceedings of the 2010 1st International Nuclear and Renewable Energy 2010 1st International Nuclear and Renewable Energy Conference (INREC10), Amman, Jordan, March 2010. 

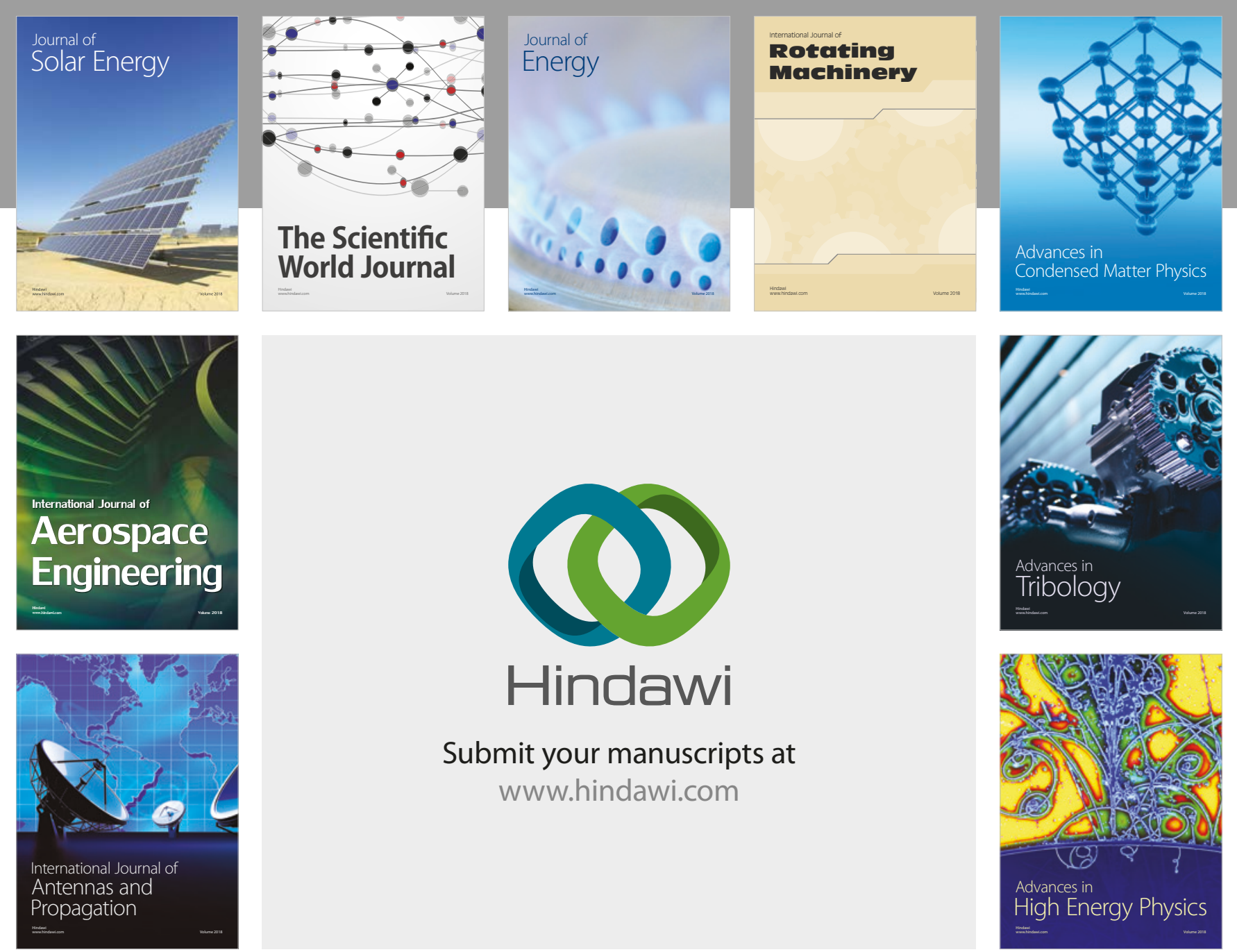

Submit your manuscripts at

www.hindawi.com
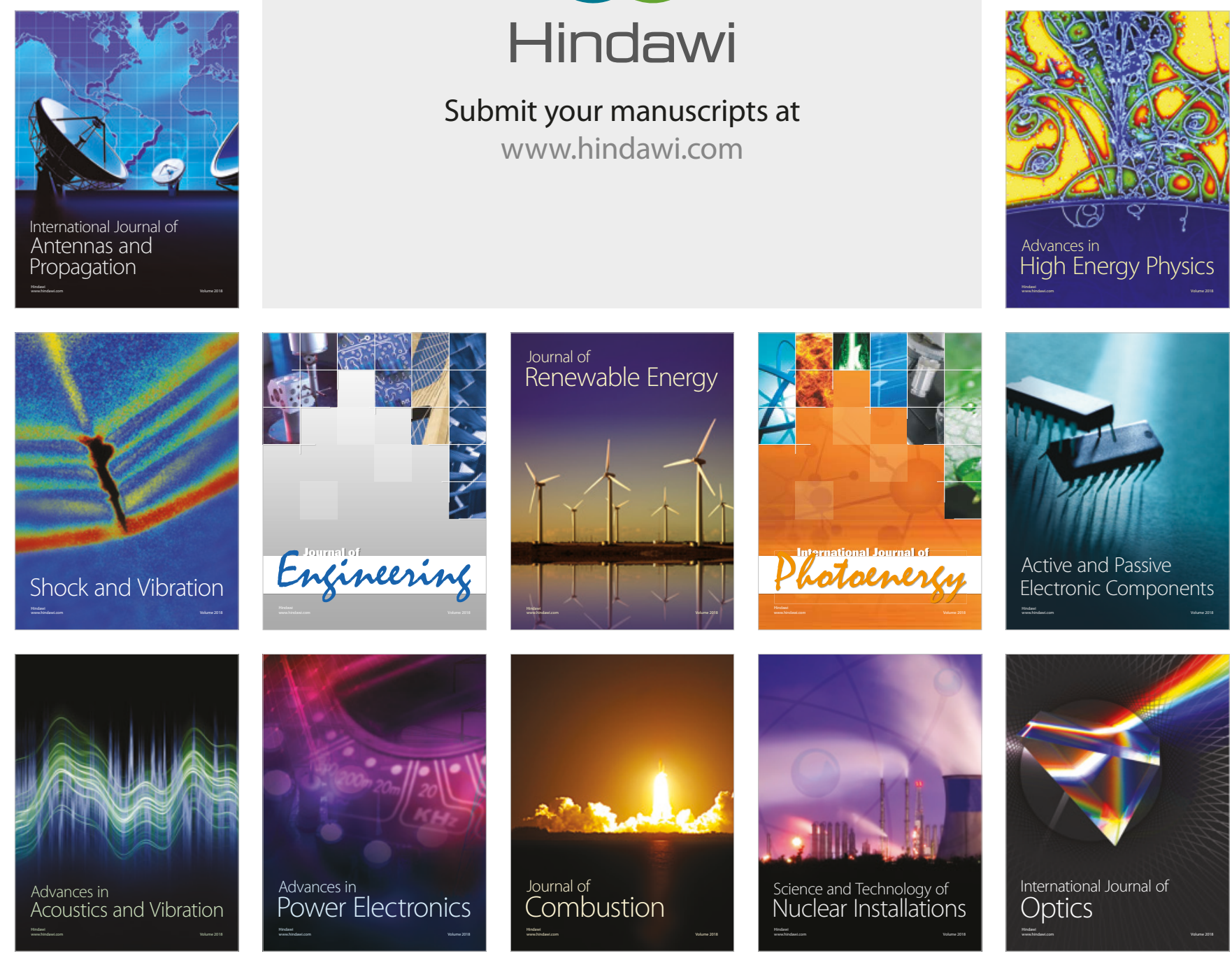